\title{
Deriving mass balance and calving variations from reanalysis data and sparse observations, Glaciar San Rafael, northern Patagonia, 1950-2005
}

\author{
M. Koppes ${ }^{1}$, H. Conway ${ }^{2}$, L. A. Rasmussen ${ }^{2}$, and M. Chernos ${ }^{1}$ \\ ${ }^{1}$ Department of Geography, University of British Columbia, 1984 West Mall, Vancouver, BC V6T 1Z2, Canada \\ ${ }^{2}$ Department Earth \& Space Sciences, University of Washington, Box 351310, Seattle, WA 98195-1310, USA
}

Received: 29 March 2011 - Published in The Cryosphere Discuss.: 14 April 2011

Revised: 14 September 2011 - Accepted: 17 September 2011 - Published: 29 September 2011

\begin{abstract}
Mass balance variations of Glaciar San Rafael, the northernmost tidewater glacier in the Southern Hemisphere, are reconstructed over the period 1950-2005 using NCEPNCAR reanalysis climate data together with sparse, local historical observations of air temperature, precipitation, accumulation, ablation, thinning, calving, and glacier retreat. The combined observations over the past $50 \mathrm{yr}$ indicate that Glaciar San Rafael has thinned and retreated since 1959, with a total mass loss of $\sim 22 \mathrm{~km}^{3}$ of ice eq. Over that period, except for a short period of cooling from 1998-2003, the climate has become progressively warmer and drier, which has resulted primarily in pervasive thinning of the glacier surface and a decrease in calving rates, with only minor acceleration in retreat of the terminus. A comparison of calving fluxes derived from the mass balance variations and from theoretical calving and sliding laws suggests that calving rates are inversely correlated with retreat rates, and that terminus geometry is more important than balance fluxes to the terminus in driving calving dynamics. For Glaciar San Rafael, regional climate warming has not yet resulted in the significant changes in glacier length seen in other calving glaciers in the region, emphasizing the complex dynamics between climate inputs, topographic constraints and glacier response in calving glacier systems.
\end{abstract}

Correspondence to: $\mathrm{M}$. Koppes

(koppes@geog.ubc.ca)

\section{Introduction}

Recent observations from Patagonia indicate widespread thinning and retreat of the outlet glaciers that drain the Patagonian Icefields (Rignot et al., 2003; Rivera et al., 2007), one of the last remaining large reserves of ice outside of the polar regions (Dyurgerov and Meier, 1997). This retreat is likely caused in part by regional warming of $\sim 0.5^{\circ} \mathrm{C}$ over the past $40 \mathrm{yr}$ (Rasmussen et al., 2007). Many of these outlet glaciers terminate in fjords or lakes, and their response to climate is complicated by their sensitivity to non-climatic influences such as terminus geometry, sediment delivery to the terminus, ice-front melt rates, and water depth (Meier and Post, 1987; Powell, 1991; van der Veen, 1996; Warren and Aniya, 1999; Motyka et al., 2003; O’Neel et al., 2005; Pfeffer, 2007; Rignot et al., 2010). Hence, retreat histories of such tidewater glaciers contain a record both of past climate and of changing ice-front dynamics.

Results from numerical models of the response of the Patagonian Icefields over glacial to interglacial timescales show that (1) glacier mass balance is sensitive to changes in large-scale atmospheric circulation, and (2) estimates of mass balance of tidewater glaciers are highly sensitive to the parameterizations used to model calving (Hulton et al., 1994; Hubbard, 1997; Cook et al., 2003). Today, as during much of the Quaternary, strong westerly winds and the orographic influence of the north-south trending Andes result in high precipitation on the western side of the Andes and relatively low precipitation on the lee side. Conditions were more arid during the early Holocene when the westerlies were weaker (Mayr et al., 2007), and may have been up to $6{ }^{\circ} \mathrm{C}$ cooler due to cooler ocean currents (Lamy et al., 2004). To better

Published by Copernicus Publications on behalf of the European Geosciences Union. 
understand how these cooler, more arid conditions may have affected the mass balance of the icefields, a closer look at the response of these outlet glaciers to recent climatic changes is needed.

In this study we use a glacier mass balance model and NCEP-NCAR reanalysis data (Kalnay et al., 1996; Kistler et al., 2001), constrained by sparse observations of local climate and glacier change to reconstruct the mass balance variations of Glaciar San Rafael, the only tidewater glacier that drains the Northern Patagonian Icefield. The icefield, also known as the Hielo Patagonico Norte (HPN - Fig. 1) extends from approx. $46.5^{\circ}$ to $47.5^{\circ} \mathrm{S}$, covering an area of $\sim 4200 \mathrm{~km}^{2}$, and the highest peak, Monte San Valentin, rises to $3910 \mathrm{~m}$. Of the 41 glaciers draining the HPN, 20 of them end in freshwater lakes or fjords. San Rafael is the only glacier in the HPN that calves into seawater; it is also the lowest latitude ocean-terminating glacier in the world. Our primary goal in reconstructing the mass balance history of Glaciar San Rafael is to document ongoing glacier and climate changes in Patagonia, one of the largest and most sensitive remaining areas of temperate ice and a potentially significant contributor to sea level rise (Rignot et al., 2003); it is also a region where little attention has been paid to glacier mass balance changes prior to the advent of cryospheric remote sensing in the late 20th century. Our secondary goal is to demonstrate how sparse glacier observations can be used to constrain a glacier mass balance history, based on global climate reanalysis data, in regions where the local and regional climate history is not well documented, in order to understand how the glacier response to recent $(50 \mathrm{yr})$ climate conditions might pertain to both earlier glacial conditions and future climatic change in the region. A further goal is to compare our observation-driven model results to a suite of calving "laws" to help interpret the dominant drivers of tidewater calving.

\section{Regional climate history}

The HPN is located in the "roaring Forties", a region characterized by a cool, wet climate throughout the year, with frequent precipitation-bearing storms. Ice cover in the region is sustained by this extreme precipitation; Escobar et al. (1992) estimated present-day annual precipitation of $6.7 \mathrm{~m}$ water equivalent averaged over the broad plateau of the HPN. Seasonal variations in precipitation and temperature are small; summers are wet and windy (Fujiyoshi et al., 1987) and precipitation can fall as snow year-round (Kondo and Yamada, 1988). Although seasonal variations are small, interannual variations in precipitation can be large (Enomoto and Nakajima, 1985); Warren and Sugden (1993) suggested that these large interannual variations in precipitation exert a strong control on glacier dynamics. They also noted that decadal mean temperature and precipitation are positively correlated; when the climate is warmer, it is also wetter.

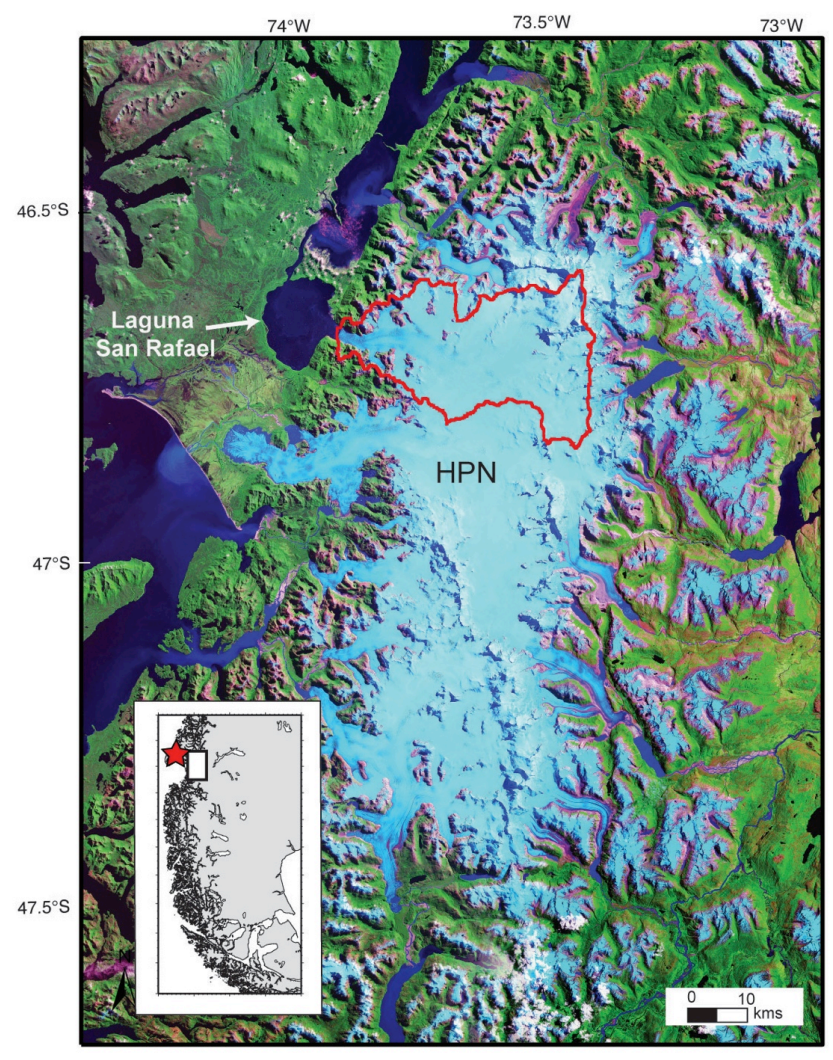

Fig. 1. Location of Glaciar San Rafael in the Campo de Hielo Patagonico Norte (HPN), Chile. Solid-line marks map extent of the glacier; dashed-line indicates present-day equilibrium line (about $1300 \mathrm{~m}$ a.s.1.). The glacier calves into Laguna San Rafael (LSR), which is connected to ocean waters through the Rio Tempano. The star shown in the inset map is the location of the NCEP-NCAR grid point SR1 at $46.67^{\circ} \mathrm{S}, 75^{\circ} \mathrm{W}$.

\section{Glacier observations}

Glaciar San Rafael descends steeply from the HPN through several icefalls, and calves into Laguna San Rafael, a brackish sea-level lagoon that is connected with the ocean by way of the Rio Tempanos (Fig. 1). A prominent arcuate moraine bounds the western side of the lagoon, while the eastern margin is an abrupt escarpment formed by the Liquine-Õfqui megafault. San Rafael is one of few tidewater glaciers in the Southern Hemisphere that has been periodically, if sparsely, monitored over the past few decades; a summary of all observations made on or near the glacier in the past $50 \mathrm{yr}$ is listed in Table 1. Aniya (1988, 1999), Warren (1993), Warren et al. (1995) and Rivera et al. (2007) documented both the retreat of the ice front over the past century and recent thinning. While the termini of many of the calving glaciers draining the western edge of the HPN have, until the most recent decade, remained near their Little Ice Age maxima, Glaciar San Rafael has steadily retreated more than $8 \mathrm{~km}$ since the 
Table 1. Summary of all climate, mass balance, surface and terminus observations made on or near San Rafael Glacier, 1950-2005.

\begin{tabular}{|c|c|c|c|}
\hline Observation type & Year & Measurement & Source \\
\hline Terminus position & $\begin{array}{l}1959 \\
1975-2001 \\
1993 \\
2005,2006\end{array}$ & $\begin{array}{l}\text { Aerial photo } \\
\text { Landsat, ASTER } \\
\text { Mapping } \\
\text { Mapping }\end{array}$ & $\begin{array}{l}\text { Koppes et al. (2010) } \\
\text { Rivera et al. (2007) } \\
\text { Warren (1993) } \\
\text { Koppes (2007) }\end{array}$ \\
\hline Terminus ice velocity & $\begin{array}{l}1983 \\
1994 \\
2001 \\
2007\end{array}$ & $\begin{array}{l}8 \mathrm{~km} \mathrm{a}^{-1} \\
4-6 \mathrm{~km} \mathrm{a}^{-1} \\
2.8-3 \mathrm{~km} \mathrm{a}^{-1} \\
6 \mathrm{~km} \mathrm{a}^{-1}\end{array}$ & $\begin{array}{l}\text { Naruse (1985); Kondo and Yamada (1988) } \\
\text { Rignot et al. (1996) } \\
\text { E. Rignot (personal communication, 2003) } \\
\text { M. Willis (personal communication, 2010) }\end{array}$ \\
\hline Calving flux & $\begin{array}{l}1993,1994 \\
2001 \\
2005,2006 \\
2007\end{array}$ & $\begin{array}{l}0.73 \mathrm{~km}^{-3} \mathrm{a}^{-1} \\
1.2 \mathrm{~km}^{-3} \mathrm{a}^{-1} \\
0.75 \mathrm{~km}^{-3} \mathrm{a}^{-1} \\
2.6 \mathrm{~km}^{-3} \mathrm{a}^{-1}\end{array}$ & $\begin{array}{l}\text { Warren et al. (1995) } \\
\text { E. Rignot (personal communication, 2003) } \\
\text { Koppes (2007) } \\
\text { M. Willis (personal communication, 2010) }\end{array}$ \\
\hline $\begin{array}{l}\text { Surface thinning } \\
\text { (ablation zone) }\end{array}$ & $\begin{array}{l}1975-2001 \\
1981-1998 \\
2001-2007 \\
1945-2005\end{array}$ & $\begin{array}{l}1.8 \pm 1 \mathrm{ma}^{-1} \\
1-2 \mathrm{~m} \mathrm{a}^{-1} \\
2.3 \mathrm{ma}^{-1} \\
2 \mathrm{ma}^{-1}\end{array}$ & $\begin{array}{l}\text { Rivera et al. (2007) } \\
\text { Aniya (1999) } \\
\text { Willis et al. (2010) } \\
\text { this study }\end{array}$ \\
\hline Ablation & 1983 & $6.8 \mathrm{~cm} \mathrm{day}^{-1}$ & Ohata et al. (1985a) \\
\hline $\begin{array}{l}\text { Accumulation } \\
\text { (icefield plateau) }\end{array}$ & $\begin{array}{l}1985 \\
1990 \\
2001\end{array}$ & $\begin{array}{l}8-10 \mathrm{~m} \mathrm{a}^{-1} \mathrm{w} . \text { eq. } \\
8-10 \mathrm{~m} \mathrm{a}^{-1} \\
4.8 \mathrm{~m} \mathrm{a}^{-1}\end{array}$ & $\begin{array}{l}\text { Fujiyoshi et al. (1987) } \\
\text { Escobar et al. (1992) } \\
\text { Carrasco et al. (2002) }\end{array}$ \\
\hline Net mass balance & $\begin{array}{l}1983 \\
1985 \\
1997\end{array}$ & $\begin{array}{l}-24.8 \mathrm{~m} \text { ice eq., terminus } \\
+3.5 \mathrm{~m} \text { w. eq., } 1300 \mathrm{~m} \text { a.s.1. } \\
+2.2 \mathrm{~m} \text {. w. eq., lee side of } \mathrm{HPN} \text {, } \\
1500 \mathrm{~m} \text { a.s.l. }\end{array}$ & $\begin{array}{l}\text { Ohata et al. (1985a) } \\
\text { Yamada (1987) } \\
\text { Matsuoka and Naruse (1999) }\end{array}$ \\
\hline $\begin{array}{l}\text { Equilibrium line alti- } \\
\text { tude (est. from sum- } \\
\text { mer snowline) }\end{array}$ & $\begin{array}{l}1986 \\
1994 \\
2002\end{array}$ & $\begin{array}{l}1250 \mathrm{~m} \text { a.s.l. } \\
1200 \mathrm{~m} \text { a.s.1. } \\
1013 \mathrm{~m} \text { a.s.l. }\end{array}$ & $\begin{array}{l}\text { Aniya (1988) } \\
\text { Rignot et al. (1996) } \\
\text { Rivera et al. (2007) }\end{array}$ \\
\hline Surface wind speed & 1983 & $4-5 \mathrm{~m} \mathrm{~s}^{-1}$, terminus & Kobayaski and Saito (1985) \\
\hline
\end{tabular}

end of the Little Ice Age, which terminated approx. 1900 AD (Araneda et al., 2007; Koppes et al., 2010).

\subsection{Surface geometry and topography}

We used data from the Shuttle Radar Topography Mission in 2000 (SRTM-2000) to construct a digital elevation model (DEM) of Glaciar San Rafael (Fig. 2). We also mapped the bathymetry of Laguna San Rafael using ship-board sonar in 2005 and 2006 (Koppes, 2007; Koppes et al., 2010) (Fig. 3) to construct the submarine terminus cross-sectional area. Analysis of the glacier DEM, which has horizontal resolution of $\sim 50 \mathrm{~m}$, indicates that the present-day area of the glacier is $728 \mathrm{~km}^{2}$ (Fig. 2); it drains $\sim 19 \%$ of the HPN icefield. Almost $40 \%$ of the surface area of the glacier lies within the "ELA zone", between $~ 1075-1460 \mathrm{~m}$, as modeled from the reanalysis data (see Sect. 4.1). Figure 7 shows the current area-altitude distribution of the glacier. The ELA zone also corresponds to the peak in orographic precipitation $k(z)$; this is discussed further in Sect. 4.2.

\subsection{Surface velocity}

Surface velocities of up to $8 \mathrm{~km} \mathrm{a}^{-1}$ have been observed near the terminus of Glaciar San Rafael, using velocity stakes measured over the month of December (summer) and extrapolated to annual velocities that are assumed to be relatively constant throughout the year (Naruse, 1985; Kondo and Yamada, 1988; Warren et al., 1995; Willis et al., 2010), making it one of the fastest flowing glaciers worldwide. Rignot et al. (1996) used synthetic aperture radar interferometry (InSAR) and feature tracking methods to measure the longitudinal surface velocity profile in 1994. Measurements from 1994 show centerline velocities that decreased from 4$6 \mathrm{~km} \mathrm{a}^{-1}$ a near the terminus, to $1.3 \mathrm{~km} \mathrm{a}^{-1} 6 \mathrm{~km}$ upglacier from the terminus, to $1.1 \mathrm{~km} \mathrm{a}^{-1}$ near the equilibrium line 


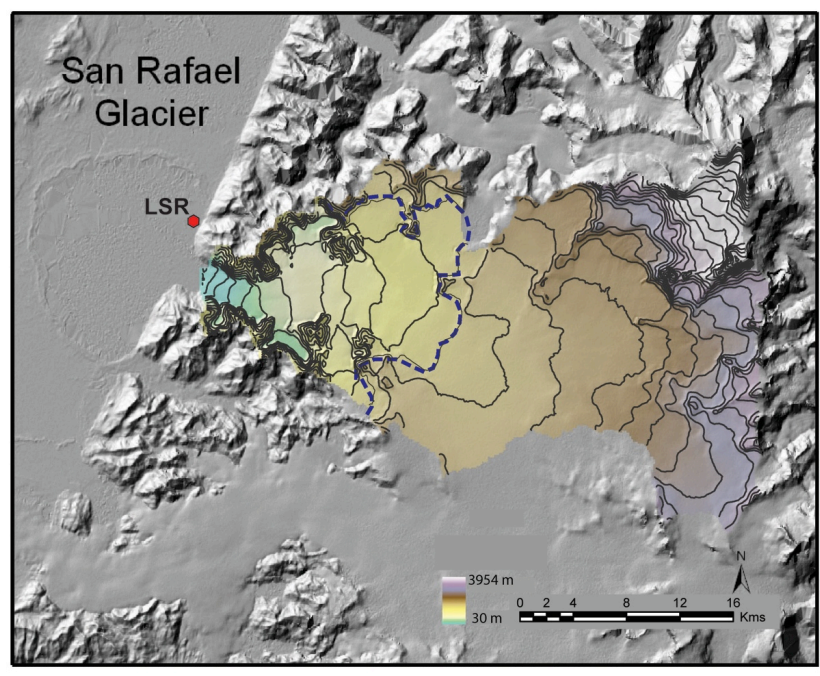

Fig. 2. Digital elevation model of Glaciar San Rafael obtained from SRTM-2000 data. Dashed blue line represents the mean ELA. 100$\mathrm{m}$ contours are indicated in thin black lines. Measurements of daily temperature and precipitation were collected at CONAF field station LSR, along the Andean rangefront.

( $\sim 1200$ m a.s.1., $17 \mathrm{~km}$ upglacier from the terminus). Additional InSAR measurements from Radarsat images taken in 2001 show surface velocities near the terminus decreased to $2.8-3 \mathrm{~km} \mathrm{a}^{-1}$ (E. Rignot, personal communication, 2003) and $2.6 \mathrm{~km} \mathrm{a}^{-1}$ in 2007 (M. Willis, personal communication, 2010). We note that these velocities were measured by tracking features on the glacier surface, and hence include both longitudinal strain rates and crevasse opening rates; true terminus velocities could be smaller, and the ice flux delivered to the terminus calculated using these velocities would be correspondingly smaller; hence, these ice velocities represent an upper bound for modeling calving rates.

\subsection{Calving}

Glaciar San Rafael remains an actively calving glacier; calving events from both above and below the waterline occur every few minutes. Warren et al. (1995) observed calving events during the summers of 1993 and 1994 and estimated that the mean summer calving flux was $\sim 2 \times 10^{-3} \mathrm{~km}^{3} \mathrm{day}^{-1}$, with an annual flux of $0.73 \mathrm{~km}^{3} \mathrm{a}^{-1}$, assuming that calving rates do not vary appreciably across the seasons. We are confident in such an assumption, as our observations of calving events during midwinter 2005 and again in autumn 2006 indicated similar calving fluxes of $0.75 \mathrm{~km}^{3} \mathrm{a}^{-1}$. Both estimates are slightly less than estimates from InSAR-derived velocities in 2001 and ASTERderived velocities from 2007 near the terminus: terminus velocities of $2.8 \mathrm{~km} \mathrm{a}^{-1}$ in 2001 (E. Rignot, personal communication, 2003), and up to $6 \mathrm{~km} \mathrm{a}^{-1}$ (Willis et al., 2010) during a two-week period in 2007, coupled with a 2001-2007 terminus ice front area of $0.42 \mathrm{~km}^{2}$ derived from the lagoon bathymetry, imply that the calving flux derived from satellite remote sensing in 2001 was $\sim 1.2 \mathrm{~km}^{3} \mathrm{a}^{-1}$, and in 2007 was up to $\sim 2.6 \mathrm{~km}^{3} \mathrm{a}^{-1}$ (M. Willis, personal communication, 2010).

\subsection{Retreat history}

Glaciar San Rafael has been in stop-start retreat throughout the 20th century. Since 1978, the glacier has retreated into a narrowing valley that crosses the Andean range front, and the terminus has changed from an extensive piedmont lobe approx. $7 \mathrm{~km}$ wide, to a narrow $\sim 2 \mathrm{~km}$ calving front. Figure 3 shows a compilation of terminus positions that we derived from: (1) aerial photos taken by the Chilean and US Air Forces in 1945 and 1959; (2) Landsat and ASTER images collected since 1979; (3) field observations, including a series of paint marks on the northern fjord wall that marked the yearly position of the northern edge of the calving cliff from 1983 to 2002; (4) measurements using ship-borne radar in 2005 and 2006; and (5) observations collated by Warren (1993). Anecdotal evidence from the Chilean Park Service, as well as these observations, suggest that although Glaciar San Rafael has experienced short-term, seasonal advances of the terminus, it has not experienced a multi-year re-advance at any time during the past $50 \mathrm{yr}$. Given the evidence, we assume that the terminus was either stable or retreating between years in which the terminus position was mapped, and we interpolate the rate of retreat between the known locations of the terminus over time using a cubic spline (Fig. 4).

Prominent trimlines along the valley walls provide a history of ice thickness change during this period. Rivera et al. (2007) compared Landsat MSS and ETM+ images from 1975 and 2001 and estimated an average thinning of the icefield surface of $1.8 \pm 1.0 \mathrm{~m} \mathrm{a}^{-1}$ around the outer margins of the HPN (including the terminal zones and lateral margins of the ablation areas of the outlet glaciers), with most of the outlet glaciers either maintaining stable terminus positions or in slow retreat. Similar rates of thinning $\left(1-2 \mathrm{~m} \mathrm{a}^{-1}\right)$ over the ablation zone of San Rafael were estimated by Aniya (1999) between 1981 and 1998 using photogrammetric methods, as well as by Willis et al. $\left(2010 ; \sim 2.3 \mathrm{~m} \mathrm{a}^{-1}\right)$ between $2001-$ 2007 using repeat ASTER satellite imagery. In July 2005, we measured a prominent trimline $120 \mathrm{~m}$ directly above the terminus ice cliff using a laser rangefinder. An early photo taken by the Chilean Air Force shows that the glacier surface was at this trimline in 1945; thinning in the vicinity of the present-day terminus has therefore averaged $\sim 2 \mathrm{~m} \mathrm{a}^{-1}$ since 1945.

In 2005-2006, the glacier terminated in an ice cliff 2-km wide (see Fig. 3). We used a laser rangefinder to determine that the top of the ice cliff varied from 30 to $70 \mathrm{~m}$ above water line. Our bathymetric measurements indicate that the glacier terminates in water up to $256 \mathrm{~m}$ deep near the centerline, with 


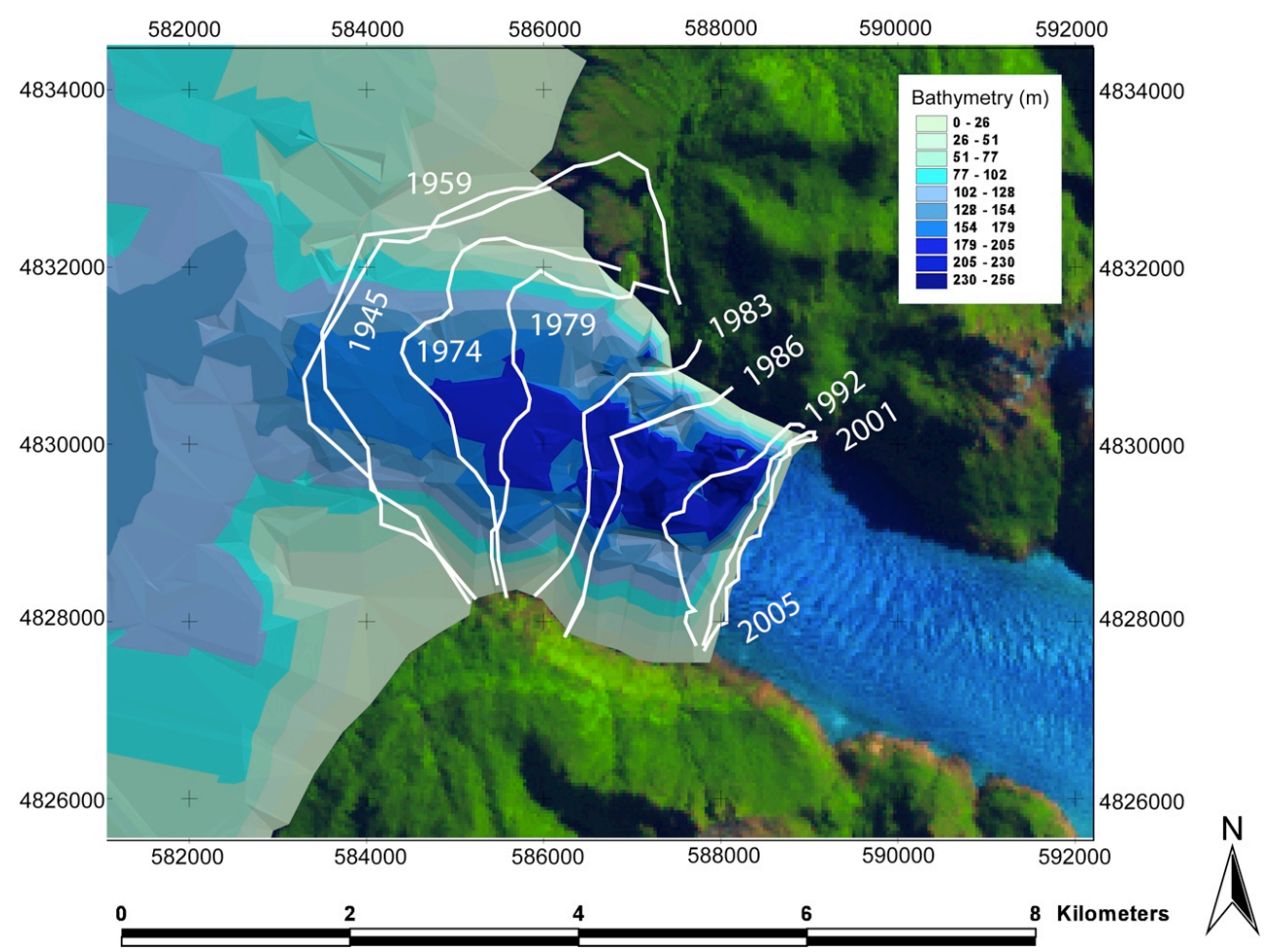

Fig. 3. Terminus positions of Glaciar San Rafael from 1945 to 2006, and bathymetry of Laguna San Rafael. The terminus was relatively stationary between 1945 and 1959, and again between 2001 and 2006. Bathymetry was mapped using ship-board sonar in 2005 and 2006.

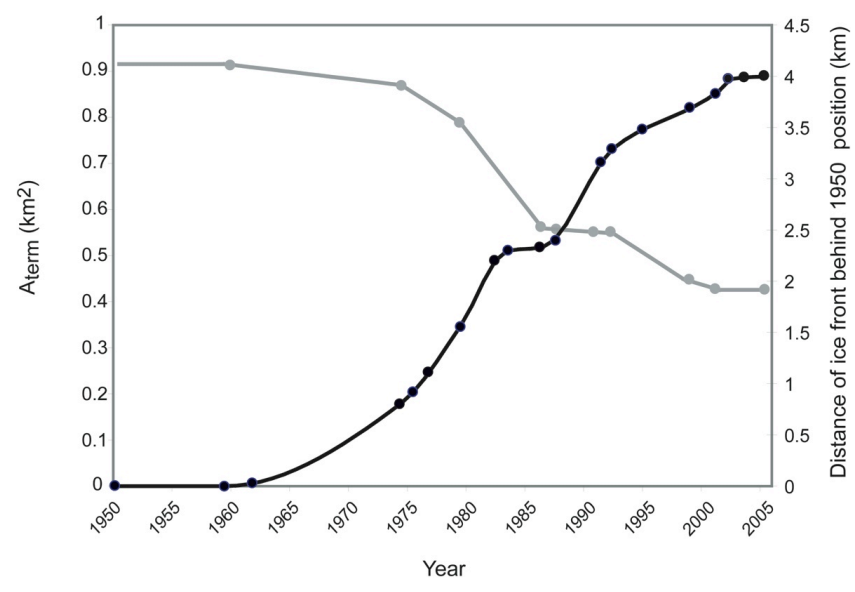

Fig. 4. History of the ice-front area $A_{\text {term }}$ (grey line) calculated from the bathymetry of Laguna San Rafael, known terminus positions (black dots), and interpolated terminus positions (black line) (see Fig. 3). For the calculation of changes in $A_{\text {term }}$ over time we assume that, on average, the cliff height across the terminus was $40 \mathrm{~m}$ above the water line.

water depths decreasing to $\sim 140 \mathrm{~m}$ on either side of a narrow central trough; the 2005 area of the terminus $A_{\text {term }}$ above and below the waterline is $0.42 \mathrm{~km}^{2}$ (Fig. 4). We estimate the annual history of the terminus area $A_{\text {term }}$ from 1950 to
2005 using the interpolated terminus locations and our new high resolution map of the bathymetry of Laguna San Rafael (Fig. 3), assuming that the average ice cliff height of $40 \mathrm{~m}$ above water line did not change appreciably during this time. Results in Fig. 4 show a marked change in terminus area (and sharp decrease in the annual rate of retreat) when the calving front retreated into the narrowing valley in the early 1980s.

\subsection{Ablation}

Measurements by Ohata et al. (1985a, b) from a network of 17 stakes set along a transect extending from near the terminus of Glaciar San Rafael up to 1050 m a.s.l. indicated that the average rate of ablation near the terminus during December 1983 was $6.8 \mathrm{~cm} \mathrm{day}^{-1}$ in ice eq., with daily-average ice ablation decreasing with elevation at a rate of $6 \mathrm{~cm} \mathrm{~km}^{-1}$. We use concurrent temperature measurements made at Laguna San Rafael in December 1983 by Enomoto and Nakajima (1985), together with temperature lapse rate profiles $T(z)$ from the NCEP-NCAR data for the same time period (Sect. 4.1), to establish a relationship between daily-average ablation $\dot{a}(z)$ temperature $T(z)$, considering only $T(z)>0$ ${ }^{\circ} \mathrm{C}$ :

$\dot{a}(z)=0.66 T(z)$ [ice] $\left(r^{2}=0.40, n=49, p<0.0001\right)$

where $\dot{a}(z)$ is in $\mathrm{cm} \mathrm{day}^{-1}$ ice eq. It should be noted that the ablation stakes used to derive Eq. (1a) were all drilled in ice 
(Ohata et al., 1985a) and reflect ablation over a local daily mean temperature range of 5 to $13^{\circ} \mathrm{C}$. To estimate ablation of snow, we follow results of Hock (2003) for similar temperate glacial systems in Norway, Iceland and the Alps and assume that the positive degree-day (PDD) factor for snow is $0.6 \pm 0.1$ that for ice. That is, for snow:

$\dot{a}(z)=0.39 T(z) \quad[$ snow $]$

In our mass balance model (Sect. 4.2), we track whether precipitation on the previous day fell above or below the daily snowline (where $T<2{ }^{\circ} \mathrm{C}$ ), and then choose either Eq. (1a) or Eq. (1b) to estimate daily ablation at $(z)$ accordingly. This is obviously a source of uncertainty in the model, as we assume that any snow that might have fallen when $T<2{ }^{\circ} \mathrm{C}$ will be ablated away if in the following days $T>0{ }^{\circ} \mathrm{C}$, and thereafter the ice ablation co-efficient will apply. This will tend to overestimate the ablation rate, but only during the start of the melt season near the snowline as the snowline is rising but the model is estimating snow removal faster than may be actually be occurring.

\subsection{Surface mass balance and equilibrium line altitudes}

The few point measurements of annual mass balance that have been collected near San Rafael glacier range from $-24.8 \mathrm{~m}$ ice eq. at the terminus in 1983 (Ohata et al., 1985a), $+3.5 \mathrm{~m}$ w. eq. at an elevation of $1296 \mathrm{~m}$ a.s.l. on the icefield plateau during 1985 (Yamada, 1987), and $+2.2 \mathrm{~m}$ w. eq. at an elevation of $1500 \mathrm{~m}$ a.s.l. on Glacier Nef on the lee (east) side of the icefield during 1997 (Matsuoka and Naruse, 1999). Although sparse, these observations provide useful targets for tuning both the precipation enhancement factor $k(z)$ to estimate the accumulation profile (see Sect. 4.1, Eq. 4), and the two ablation PDD co-efficients (Eq. 1a and 1b). Equilibrium line altitude (ELA) observations from prior studies are: 1250 m a.s.l. in 1986 (Aniya, 1988), 1200 m a.s.l. in 1994 (Rignot et al., 1996) and $1013 \mathrm{~m}$ a.s.l. in 2002 (Rivera et al., 2007). These provide additional constraints for tuning the mass balance model (see Sect. 4.2).

\section{Glacier mass budget model}

\subsection{Reconstructing local surface mass balance 1950-2005}

The NCEP-NCAR Reanalysis climate database is derived from historical observations of various meteorological variables made at the surface, from radiosondes and from satellites (Kalnay et al., 1996; Kistler et al., 2001). The database consists of 6-hourly estimates of meteorological variables at standard atmospheric pressure levels on a $1.9^{\circ}$ global grid extending back to January 1948. The nearest NCEP-NCAR surface gridpoint to Glaciar San Rafael, at $46.67^{\circ} \mathrm{S}, 75^{\circ} \mathrm{W}$, is shown as a star in Fig. 1 and henceforth referred to as
SR1. Located to the west of the glacier, near the coast, gridpoint SR1 was chosen to best reflect the dominant synoptic weather patterns upstream of the study area. Rasmussen et al. (2007) used the NCEP-NCAR data to show that the 850hPa precipitation flux at $45^{\circ} \mathrm{S}$ (calculated from $U_{850} \mathrm{RH}_{850}$ where $U_{850}$ is the component of the wind from direction $270^{\circ}$ and $\mathrm{RH}_{850}$ is the relative humidity) decreased by about $10 \%$ over 1948-1998. However, the fraction falling as snow at $850 \mathrm{hPa}$ (calculated from $U_{850} \mathrm{RH}_{850}$ when $T \leq 2{ }^{\circ} \mathrm{C}$ ) decreased by about $20 \%$; hence, the combined effects of warming and drying have caused the $850-\mathrm{hPa}$ snowfall at $45^{\circ} \mathrm{S}$ to decrease by about $28 \%$.

Although we show model results from 1950 to 2005 using the NCEP-NCAR dataset, caution is needed when interpreting results from 1950 to 1960 because of inhomogeneities in the instrumental record in the late 1950s (see Rasmussen et al., 2007). For this reason, herein we focus our statistical and model analysis on climate and glacier changes from 1960 to 2005; however, we include the entire record available to 1950 in our model runs, with caveat above, as the terminus record suggests that the ice front was unusually stable from 1950-1959.

We compared the NCEP-NCAR derived climate data from SR1 with a record of 398 daily temperature and precipitation measurements that we made between March 2005 and April 2006 at a Chilean Forest Service (CONAF) guard station, located about $7 \mathrm{~km}$ from the glacier front on the shores of Laguna San Rafael (LSR, at $46.66^{\circ} \mathrm{S}, 73.86^{\circ} \mathrm{W}$ ). We used two tipping bucket rain gauges $(0.2 \mathrm{~mm}$ per tip) and a 2 -channel temperature sensor. Air temperature (measured $1.4 \mathrm{~m}$ above the surface) and soil temperature (measured $2 \mathrm{~cm}$ below the surface) were recorded hourly. Figure 5 shows daily-average temperature and precipitation measurements at LSR, and NCEP-NCAR derived values at the 1000-hPa level at SR1. A linear regression of temperatures over the period of record yields:

$$
\begin{aligned}
T_{\mathrm{LSR}} & =0.73 T_{\mathrm{SR} 1}+5.5 \\
\left(r^{2}\right. & =0.77 ; n=398 ; p<0.0001)
\end{aligned}
$$

where $T_{\mathrm{LSR}}$ is the daily-average air temperature $\left({ }^{\circ} \mathrm{C}\right)$ at $\mathrm{La}$ guna San Rafael, and $T_{\mathrm{SR} 1}$ is the daily-average 2-m air temperature at SR1.

The correlation between the temperatures measured at LSR and NCEP-NCAR derived surface temperatures at SR1 (Eq. 2) show a good fit $\left(r^{2}=0.77\right)$, with temperatures at Laguna San Rafael on average $5^{\circ} \mathrm{C}$ warmer than at SR1 (Fig. 5a). In contrast, the precipitation-correlation over the same period is weak, accounting for less than half the variance $\left(r^{2}=0.48\right)$ (Fig. 5b); although the NCEP-NCAR values capture the timing of storm events well, the magnitude of the larger storms is generally underestimated, in part due to reliance on model derivations (precipitation is a type $C$ variable, so there are no direct measurements used to constrain the reanalysis values; Kistler et al., 2001). The correlation 

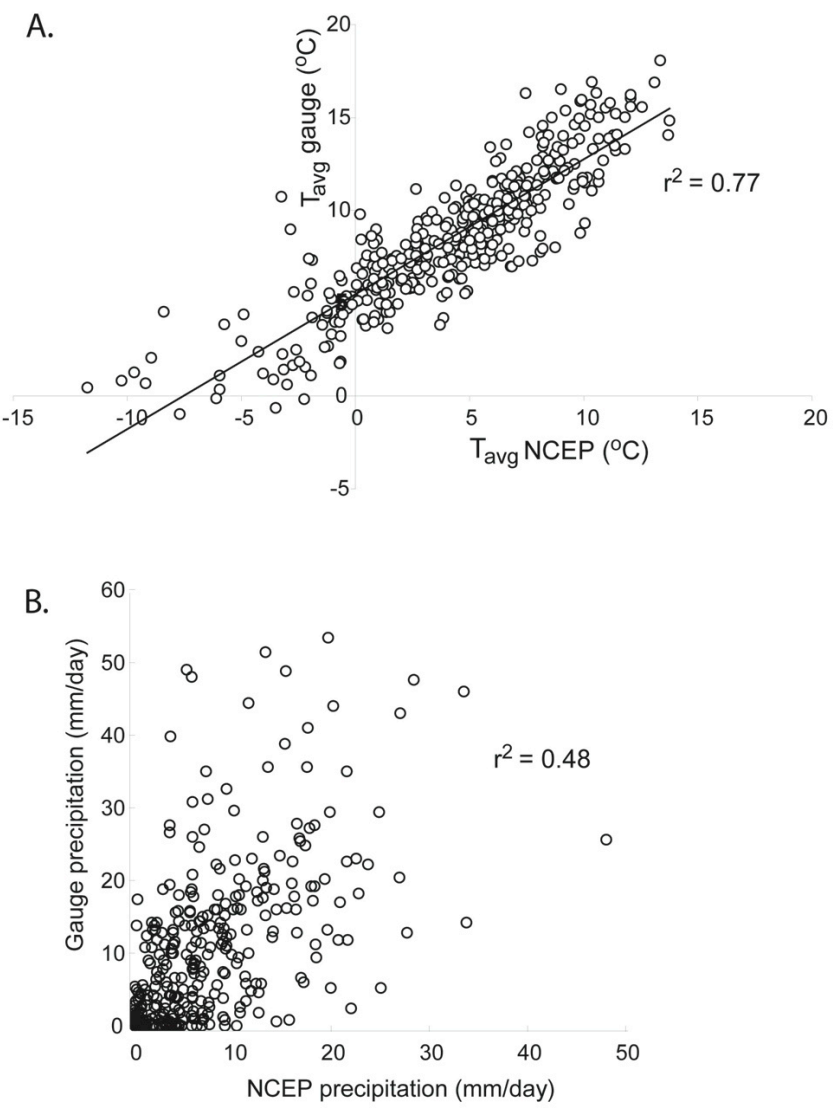

Fig. 5. Comparison of 398 daily-average measurements of temperature (a) and precipitation (b) made at Laguna San Rafael from March 2005 to April 2006, with NCEP-NCAR derived values at $2 \mathrm{~m}$ above ground at gridpoint SR1. Correlation co-efficients are 0.77 and 0.48 , respectively.

is improved by including the zonal wind speed $U_{\mathrm{SR} 1}\left(\mathrm{~m} \mathrm{~s}^{-1}\right)$ modeled at $10 \mathrm{~m}$ above ground to reflect the magnitude of storm intensity:

$$
\begin{gathered}
P_{\mathrm{LSR}}=0.78 P_{\mathrm{SR} 1}+0.9\left|U_{\mathrm{SR} 1}\right|+0.82 \\
\left(r^{2}=0.50 ; n=398 ; p<0.0001\right)
\end{gathered}
$$

where $P_{\mathrm{LSR}}$ and $P_{\mathrm{SR} 1}$ are daily precipitation in $\mathrm{mm}$ at Laguna San Rafael and the NCEP-NCAR gridpoint SR1, respectively. We note that wind speeds measured near the terminus of San Rafael in 1983 were $\sim 4-5 \mathrm{~m} \mathrm{~s}^{-1}$ (Kobayashi and Saito, 1985), while NCEP-NCAR derived winds at SR1 are typically $2-3$ times stronger $\left(10-15 \mathrm{~m} \mathrm{~s}^{-1}\right)$ for the same period.

We calculate the uncertainties in our statistical downscaling approach using the leave-one-out cross-validation method, wherein multiple monthly blocks of data were removed from the local calibration dataset ( $P_{\mathrm{LSR}}$ and $T_{\mathrm{LSR}}$ ) and a new linear regression with the NCEP-NCAR dataset (Eqs. 2, 3) was performed in order to estimate errors from the least squares regression. The regression coefficients (and uncertainties) are determined as the means of coefficients from each repetition of the model fitting procedure in the cross-validation experiment (cf. Hofer et al., 2010). The maximum estimated uncertainties using our cross-validation scheme was $\pm 0.7^{\circ} \mathrm{C}$ for $T_{\text {avg }}$ and $\pm 4 \mathrm{~mm} \mathrm{day}^{-1}$ for $P_{\mathrm{LSR}}$, respectively.

We use Eq. (2) and the NCEP-NCAR database to hindcast daily-average temperatures at the terminus of Glaciar San Rafael from 1950 to 2005. We also use the NCEPNCAR upper air temperatures from 1000, 925, 850, 700, and $600 \mathrm{hPa}$ levels to reconstruct daily variations in the atmospheric lapse rate at SR1. The average lapse rate over the period of record was $5.5 \pm 0.9^{\circ} \mathrm{C} \mathrm{km}^{-1}$, similar to lapse rates measured by Kerr and Sudgen (1994). We used the daily temperature at LSR (calculated using Eq. 2) and the daily lapse rates from SR1 to reconstruct $T(z)$ from sea level to the top of the glacier. Daily $T(z)$ profiles are needed to partition the snow-fraction of precipitation and to estimate ablation (Sect. 3.5) over the glacier surface.

Figure 6a shows variations of mean annual temperature variations at Laguna San Rafael over the period 1950-2005, derived from the NCEP-NCAR record. Mean annual temperatures at the glacier front varied only $1.3^{\circ} \mathrm{C}$ about a mean of $8.9^{\circ} \mathrm{C}$, consistent with the strong maritime influence on the climate of the region.

We use Eq. (3) to estimate daily precipitation at Laguna San Rafael over the same period 1950-2005. Annual precipitation there has varied by $\pm 0.60 \mathrm{~m}$ about a mean of $3.60 \mathrm{~m}$ (Fig. 6b). Precipitation, which was relatively high during the period 1960-1975, decreased by more than $13 \%$ during the period 1976 to 2005.

To estimate daily precipitation in the form of snowfall over the surface of the glacier $P(z)$ over the period 1950-2005, we scaled $P_{\mathrm{LSR}}$ by an orographic enhancement factor $k(z)$ that varies spatially, so that:

$P(z)=k(z) P_{\mathrm{LSR}}$

The enhancement factor $k(z)$ is not well constrained; sparse observations and model results suggest that precipitation on the plateau of the Northern Patagonian Icefield, $\sim 10 \mathrm{~km}$ upwind of the Andean crest, is 2.5 to 5 times that on the outer coast to the west of Laguna San Rafael (Fujiyoshi et al., 1987; Escobar et al., 1992; Carrasco et al., 2002); observations from the Southern Alps of New Zealand, a similar north-south trending mountain belt protruding into the Southern Westerlies, also indicate that precipitation increases to a peak $20 \mathrm{~km}$ upwind of the divide that is $4-5$ times that on the western coast (Wratt et al., 2000). To test the sensitivity of the enhancement factor $k(z)$, we ran our accumulation model using a range of static values from $k=3$ to $k=5$ at all elevation $z$ (see Sect. 4.2).

We also ran a scenario wherein we assume $k$ increases with altitude according to a simplified 1-D orographic model. We implemented Smith and Barstad's linear numeric orographic precipitation model over the centerline topographic profile 
A.

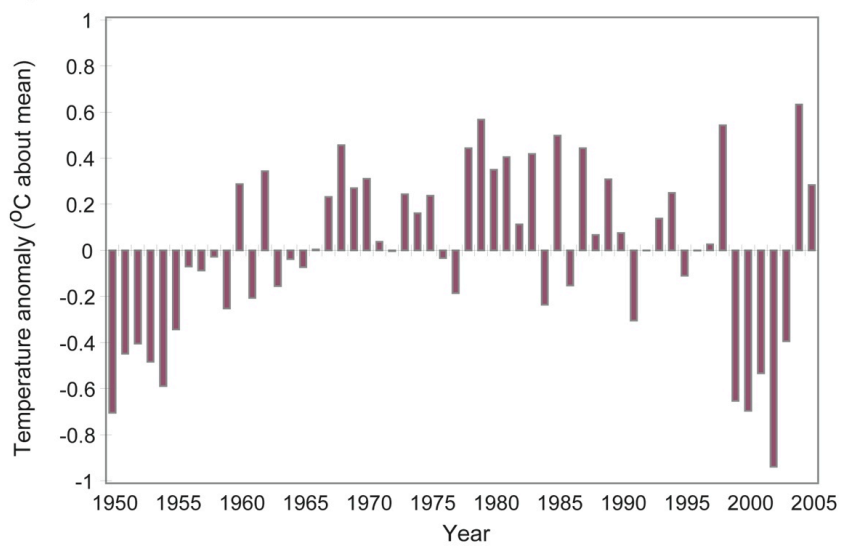

B.

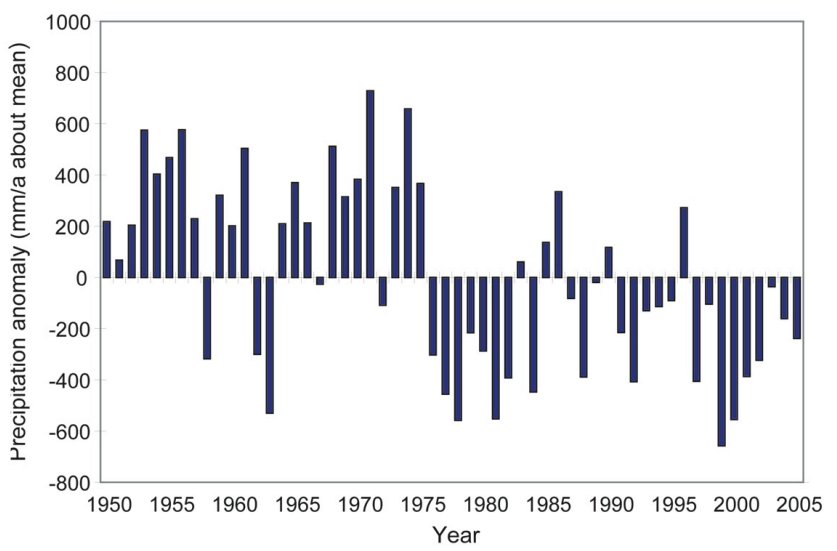

Fig. 6. Reconstructed annual temperature (a) and precipitation (b) anomalies at Laguna San Rafael for the period 1950 to 2005. Local values were calculated using NCEP-NCAR data and the relationships established in Eqs. (1) and (2). Anomalies shown are differences from the mean value for the period: mean annual temperature was $8.9^{\circ} \mathrm{C}$; mean annual precipitation at LSR was $3.60 \mathrm{~m}$ w. eq.

of the glacier surface (Smith and Barstad, 2004; Roe, 2005). Whereas the factor $k$ varies as a function of glacier surface elevation $(z)$ in this orographic model, it is also possible to calculate it as a function of distance from the coast and rangefront $(x)$, because the elevation of the glacier surface itself is a function of that distance (see Fig. 2). Cloud microphysics in the model are represented by characteristic time delays for hydrometeor growth and fallout. The large-scale atmospheric flow is computed as a function of wind and temperature, and the amplitude and pattern of precipitation are then calculated as a function of that flow. Tunable model parameters include the horizontal wind speed $(u)$, meteoric fallout rate $\left(\tau_{\mathrm{f}}\right)$, conversion time $\left(\tau_{\mathrm{c}}\right)$, moisture scale height $\left(H_{\mathrm{m}}\right)$, and moist static stability for upward convection $\left(N_{\mathrm{m}}\right)$. We tuned the orographic model so that the average precipitation at the coast $\left(\sim 1.8 \mathrm{~m} \mathrm{a}^{-1}\right)$ (Carrasco et al., 2002) increases by a factor of two to match observations at Laguna San Rafael $\left(\sim 3.6 \mathrm{~m} \mathrm{a}^{-1}\right), \sim 20 \mathrm{~km}$ inland, and by a factor of

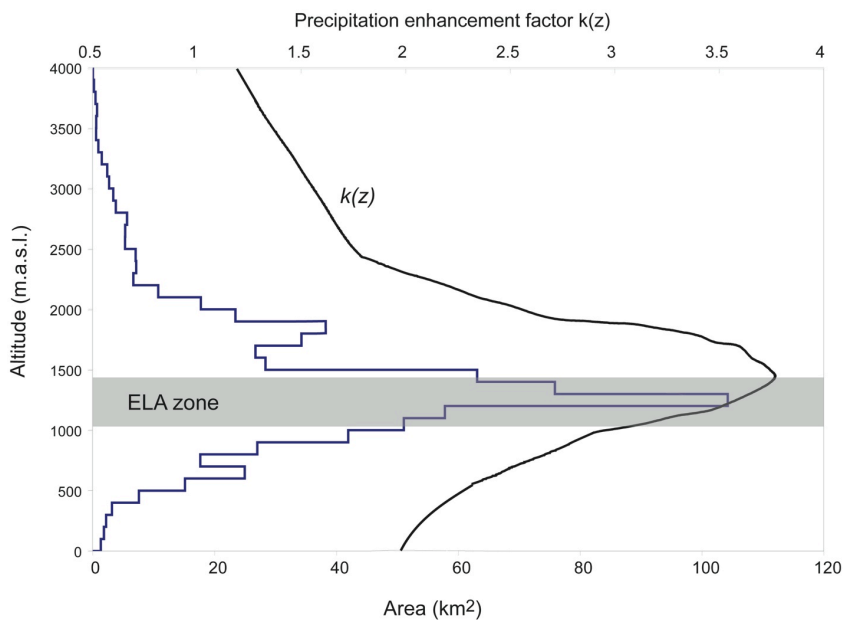

Fig. 7. Year $2000 \mathrm{AD}$ area-altitude distribution of Glaciar San Rafael, in 100-m. altitude intervals, derived from SRTM data, and spatial variation in the precipitation enhancement factor $k(z)$ (black line) used to model precipitation on the glacier surface. The enhancement factor is a multiple of precipitation at the coast. The zone of equilibrium line altitudes from 1960-2005 is indicated by the grey bar.

3.5 at $1200 \mathrm{~m}$ a.s.l. to match values estimated by Fujiyoshi et al. (1987) and Carrasco et al. (2002) near the equilibrium line of the glacier. The most realistic response, which produced a peak enhancement factor that best fit observations, was obtained with the following input parameters: $u=15 \mathrm{~m} \mathrm{~s}^{-1}$, $\tau_{\mathrm{f}}=\tau_{\mathrm{c}}=1000 \mathrm{~s}, H_{\mathrm{m}}=3000 \mathrm{~m}$, and $N_{\mathrm{m}}=0.005 \mathrm{~s}^{-1}$. Figure 7 shows modeled spatial variations of $k(z)$.

\subsection{Surface mass balance model}

At each elevation $z$, the annual surface mass balance $\dot{b}(z)$ is the algebraic sum of accumulation $\dot{c}(z)$ and ablation $\dot{a}(z)$ That is:

$\dot{b}(z)=\dot{c}(z)-\dot{a}(z)$

We derive daily accumulation and ablation for each elevation $z$ over the glacier surface and sum the balances at each elevation $z$ to calculate the annual total surface mass balance. Following previous work we assume that any precipitation $P(z)$ that falls when $T(z)>+2{ }^{\circ} \mathrm{C}$ is rain that runs off the glacier surface without refreezing. Conversely, when $T(z) \leq+2{ }^{\circ} \mathrm{C}$, precipitation falls as snow and accumulates on the glacier surface (Rasmussen and Conway, 2001; Roe, 2005). We calculate accumulation over the entire glacier surface daily, using Eqs. (3) and (4) and the temperature lapse rate to discriminate between rain and snow, and sum the daily accumulation to calculate the annual accumulation at each elevation $(z)$. Model results for the mean annual mass balance profiles (Fig. 8) and the equilibrium line altitude of Glaciar San Rafael for the period 1960-2005 (Fig. 9) show 


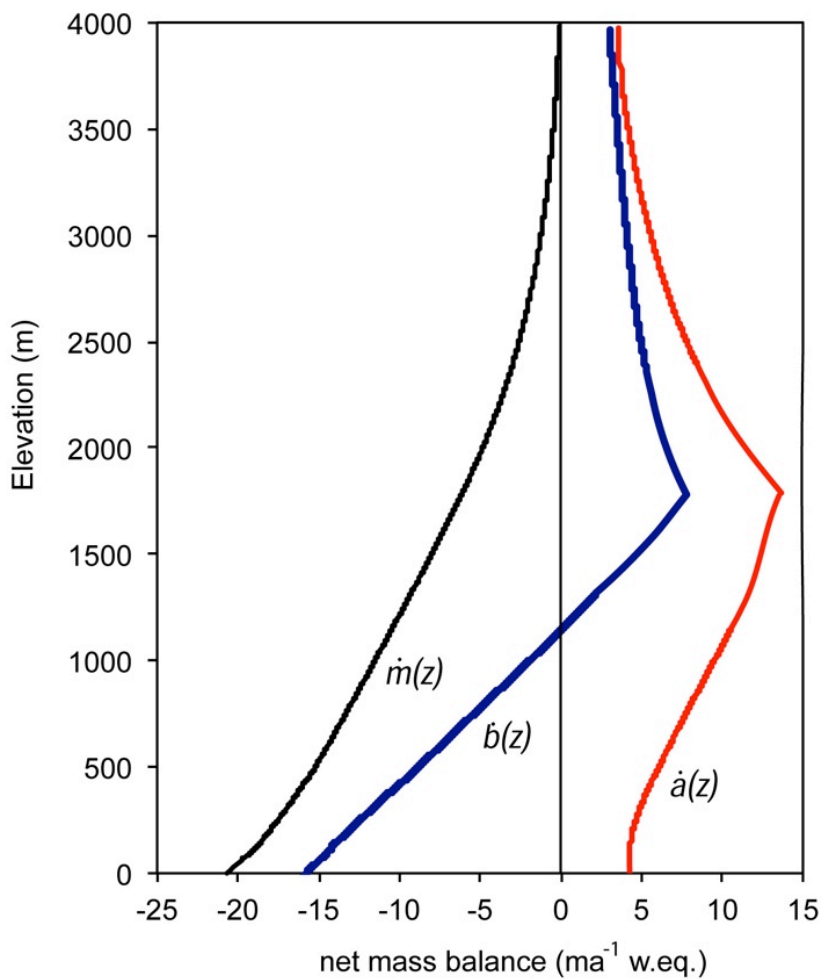

Fig. 8. Mean annual surface mass balance $b(z)$, accumulation $c(z)$ and ablation $a(z)$ derived from the mass balance model for the period 1960-2005, versus elevation. Mass balance is calculated using an orographic precipitation enhancement factor $k(z)$ from Fig. 7 and input scenario \#4 (Table 2).

that the annual ELA (i.e., where $b(z)=0$ ) ranges from 1050$1460 \mathrm{~m}$ a.s.l., with a mean ELA of $1295 \mathrm{~m}$ a.s.l.

The concentration of orographic enhancement $k(z)$ of snowfall around the elevation of the ELA $(\sim 1100$ $1400 \mathrm{~m}$ a.s.l.), as indicated by observations (Fujiyoshi et al., 1987; Escobar et al., 1992; Carrasco et al., 2002) may also be a major driver in our mass balance model. As can be seen in Fig. 8, the accumulation, and hence mass balance, gradient for this glacier shows a pronounced kink at $\sim 1700 \mathrm{~m}$ a.s.l. This kink in the mass balance profile may be due in part to limited variability in temperatures in this maritime climate, where the range of elevations over which the transition from solid to liquid precipitation occurs is narrow; it may also reflect the fact that a large percentage of the cumulative glacier surface area occurs in this same range of elevations. An orographically-induced peak in precipitation at the ELA would unrealistically tip the balance towards net accumulation if too large, or net ablation if too small. As the areaelevation distribution of this glacier is so heavily weighted in a zone across the broad plateau of the icefield at the elevation of the ELA that accounts for almost $40 \%$ of the glacier surface, any estimates of the cumulative balance over the past $50 \mathrm{yr}$ are extremely sensitive to the location and magnitude

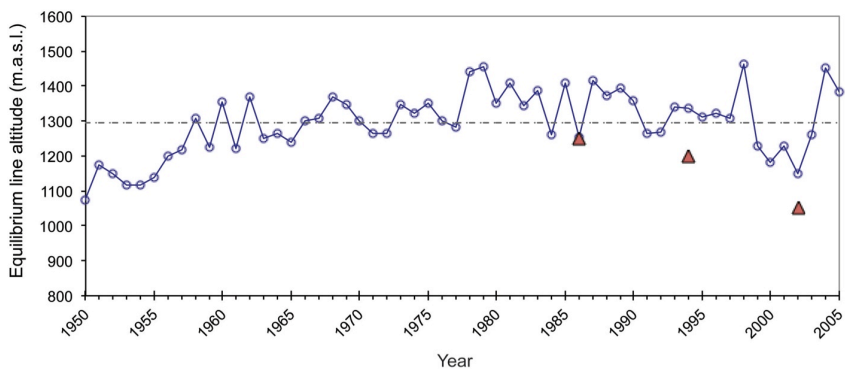

Fig. 9. Annual equilibrium line altitude (ELA) derived from daily snowline and the mass balance model using input scenario \#4 in Table 2, from 1950-2005 (black line) and measured ELAs in 1986, 1994 and 2002 (also derived from late summer snowline) (triangles). Mean modeled ELA for the period 1960-2005 is $1295 \mathrm{~m}$.

of an orographically-enhanced peak in precipitation in this zone.

\subsection{Terminus mass budget}

The fundamental equation describing fluxes near the terminus of calving glaciers is:

$\frac{d L}{d t}=\frac{Q_{\text {bal }}+Q_{\text {thin }}-Q_{\text {calv }}}{A_{\text {term }}}$

where $\frac{d L}{d t}$ is a change in the length of the glacier; $Q_{\mathrm{bal}}$ is the surface mass balance $b(z)$ integrated over the area of the glacier, and $Q_{\text {thin }}$ is the volume of ice lost due to thinning. The flux of ice away from the terminus $Q_{\text {calv }}$ includes both calving and mass loss due to submarine melting and surface ablation averaged over the area of the terminus face $A_{\text {term. }}$. A glacier is in balance when $Q_{\text {calv }}$ equals $Q_{\text {bal }}$, and the ice thickness and length are not changing. For a shrinking glacier, the ice volume decreases both through glacier shortening $Q_{\text {term }}=-\frac{d L}{d t} A_{\text {term }}$ and through surface lowering $Q_{\text {thin }}=-\frac{d h}{d t} A_{\text {thin. }}$. Glacier retreat $\frac{d L}{d t}$ can be measured from known terminus positions and $A_{\text {term }}$ can be estimated from bathymetry, glacier thinning $\frac{d h}{d t}$ and the area of thinning $A_{\text {thin }}$ can be estimated from trimlines, and surface mass balance $Q_{\text {bal }}$ can be estimated from precipitation and temperature data, and so we rearrange Eq. (6) to solve explicitly for the calving flux $Q_{\text {calv }}$, which is the volume of ice passing through the terminus per unit time:

$Q_{\text {calv }}=Q_{\text {bal }}+Q_{\text {thin }}+Q_{\text {term }}$

(see Fig. 10). Variability in the calving flux, averaged over the terminus cross-sectional area $A_{\text {term }}$, represents temporal changes in the cross-sectionally averaged calving velocity, which primarily arise from changes in sliding speeds for fast moving glaciers like San Rafael. 

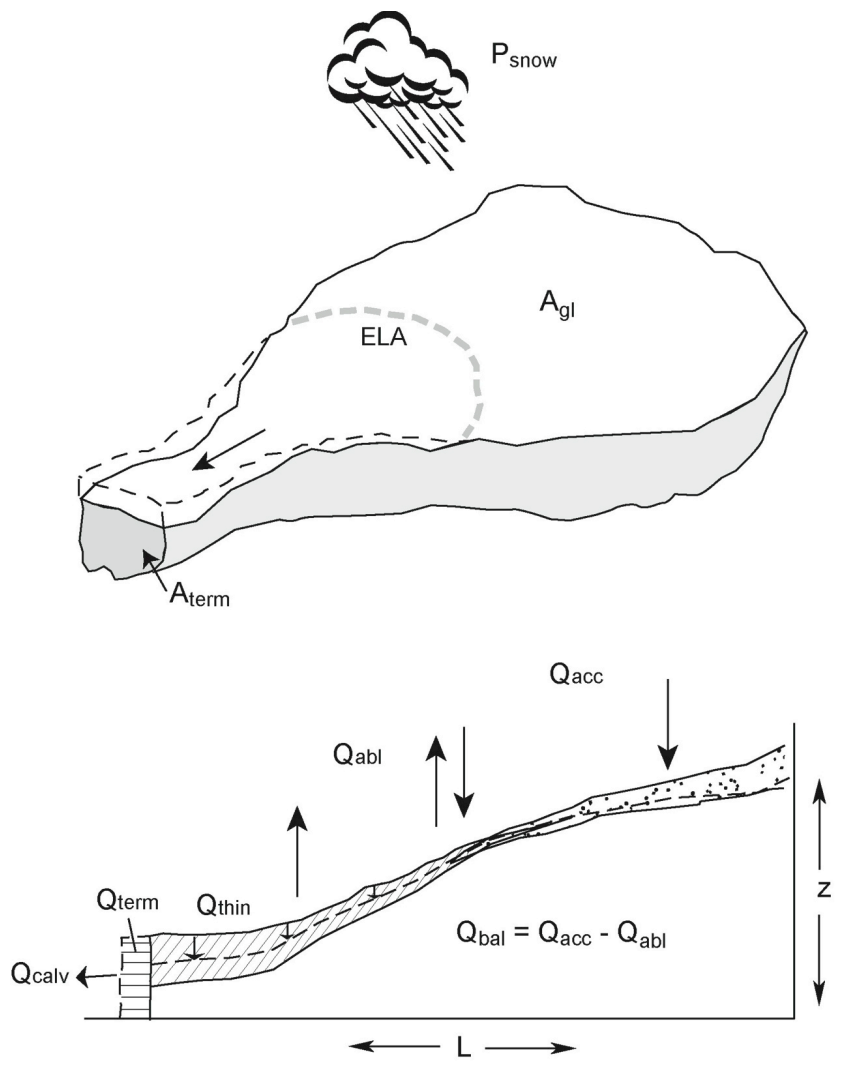

Qcalv = Qbal + Qthin + Qterm

Fig. 10. Illustration of fluxes and areas relevant for estimating the mass budget of calving glaciers.

\subsection{Calving model}

A second means of deriving the calving flux, $Q_{\text {calv }}$, can be acquired by applying a suite of empirically and theoretically derived "calving laws" (Benn et al., 2007) using the observed bathymetry of the fjord, where former locations of the calving margin are also known. In such an approach, the calving rate is quantified by combining the retreat rate $\frac{d L}{d t}$ over time with modeled terminus velocities $U_{\text {ice }}$, and then compared to ice front cross-sectional areas $A_{\text {term }}$ to compute a calving flux at annual time steps. Here, the calving velocity, $U_{\mathrm{D}}$, is defined as the difference between the average down-glacier ice velocity at the terminus and the change in terminus position in the $L$-direction over time:

$U_{\mathrm{D}}=U_{\mathrm{T}}-d L / d t$

By treating calving in this manner, quantifying the rate of ice discharge over annual timescales requires only knowledge of yearly terminus position and an average ice velocity at the terminus. However, the controls on ice velocity are substantial, and still poorly understood (e.g., Warren and Aniya, 1999; Benn et al., 2007). To reduce unnecessary complexity, for this model run we ignore longitudinal stretching and treat glacier flow resistance as a product of lateral and basal drag.

Bathymetric transects along previous ice fronts, combined with an observed average height of the ice cliff above waterline of $40 \mathrm{~m}\left(H_{0}\right)$ allows us to determine the thickness of the ice front at the terminus $\left(H_{\mathrm{T}}\right)$, using a height above buoyancy criterion (Van der Veen, 1996), assuming the ice front is at flotation:

$H_{\mathrm{T}}=\overline{U_{\mathrm{T}}}-\frac{\rho_{\mathrm{sw}}}{\rho_{\mathrm{i}}} H_{\mathrm{W}}+H_{0}$

where $\rho_{\mathrm{sw}}$ and $\rho_{\mathrm{i}}$ are the densities of seawater and ice, respectively. Water depth $\left(H_{\mathrm{W}}\right)$ hence is a primary control on ice front thickness at the terminus, and thinning will result in retreat until shallower water is reached. Once the ice thickness $H_{\mathrm{T}}$ and change in the glacier surface slope $\theta$ is known, the driving stress in the downslope direction can be quantified:

$\tau_{\mathrm{D}}=\rho_{\mathrm{i}} g H_{\mathrm{T}} \sin \theta$

This driving stress is opposed by basal resistance, which can be easily altered using only a single tuning parameter $C$ :

$\tau_{\mathrm{B}}=\tau_{\mathrm{D}}\left(1-\frac{\rho_{\mathrm{w}} H_{\mathrm{W}}}{\rho_{\mathrm{i}} H_{\mathrm{T}}}\right)^{C}$

where $\rho_{\mathrm{w}} H_{\mathrm{W}}$ is the basal water pressure, and assuming that (a) $\tau_{\mathrm{B}}=0$ when the ice pressure $\rho_{\mathrm{i}} H_{\mathrm{T}}$ equals the basal water pressure, and (b) $\tau_{\mathrm{B}}=\tau_{\mathrm{D}}$ when $\rho_{\mathrm{W}} z=0 . C$ was tuned to calibrate the calving model to observed surface velocities in 1983, 1994, and 2001 (Naruse, 1985; Rignot et al., 1996; E. Rignot, personal communication, 2003); agreement was closest when $C=0.6$. This is double the value of $C$ correlated using data from Columbia Glacier (Benn et al., 2007), which could in due in part to Columbia Glacier's more gradual slope $\left(1.15^{\circ}\right.$ versus $2.67^{\circ}$ at Glaciar San Rafael) (Venteris, 1999).

The annual velocity at the terminus was then calculated assuming a rectangular bed, using the sliding law developed in Benn et al. (2007). Mean values of basal drag, driving stress and ice thickness were used to estimate the average sliding velocity $U_{\mathrm{B}}$ at the terminus:

$U_{\mathrm{B}}=\frac{2 A}{n+1}\left(1-\frac{\tau_{\mathrm{D}}-\tau_{\mathrm{B}}}{H_{\mathrm{T}}}\right)^{n} W^{n+1}$

using a flow parameter $A$ calculated from Arrhenius' Law and $n=3$ from Glen's flow law (Nye, 1965).

For extremely fast-moving, calving glaciers such as Glaciar San Rafael, we follow the practices of prior studies in assuming that internal deformation (creep) rates are small when compared to $>3 \mathrm{~km} \mathrm{yr}^{-1}$ surface velocities, particularly near the terminus where glaciers are noted to speed up (see Howat et al., 2005; Venteris, 1999). For our purposes, we take the approach stated in Benn et al. (2007) and assume a uniform vertical velocity distribution and constant 
Table 2. Summary of modeled ice fluxes through Glaciar San Rafael, 1960-2005. Scenarios used in model runs: $\alpha 1=$ ablation flux using Eq. (1a) only; $\alpha 2=$ ablation flux calculated using Eqs. (1a) and (1b); $k(z)=$ enhancement factor used in Eq. (4). $Q_{\text {calv }}$ is calculated as in Eq. (7) as the sum of $Q_{\text {thin }}, Q_{\text {bal }}$ and $Q_{\text {term. }} Q_{\text {thin }}$ and $Q_{\text {term }}$ did not vary from case to case.

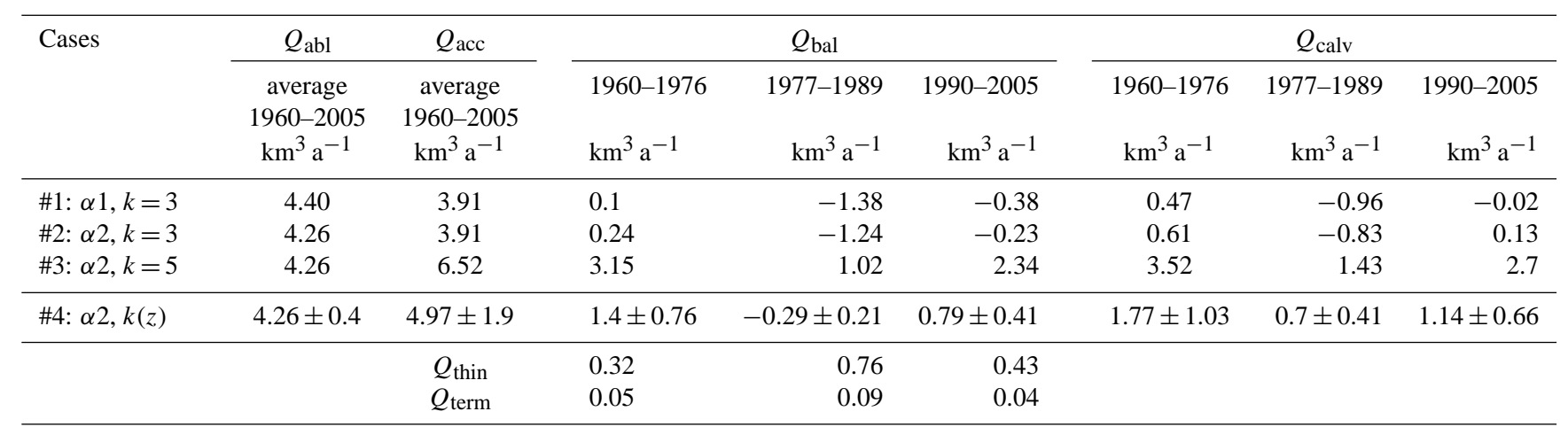

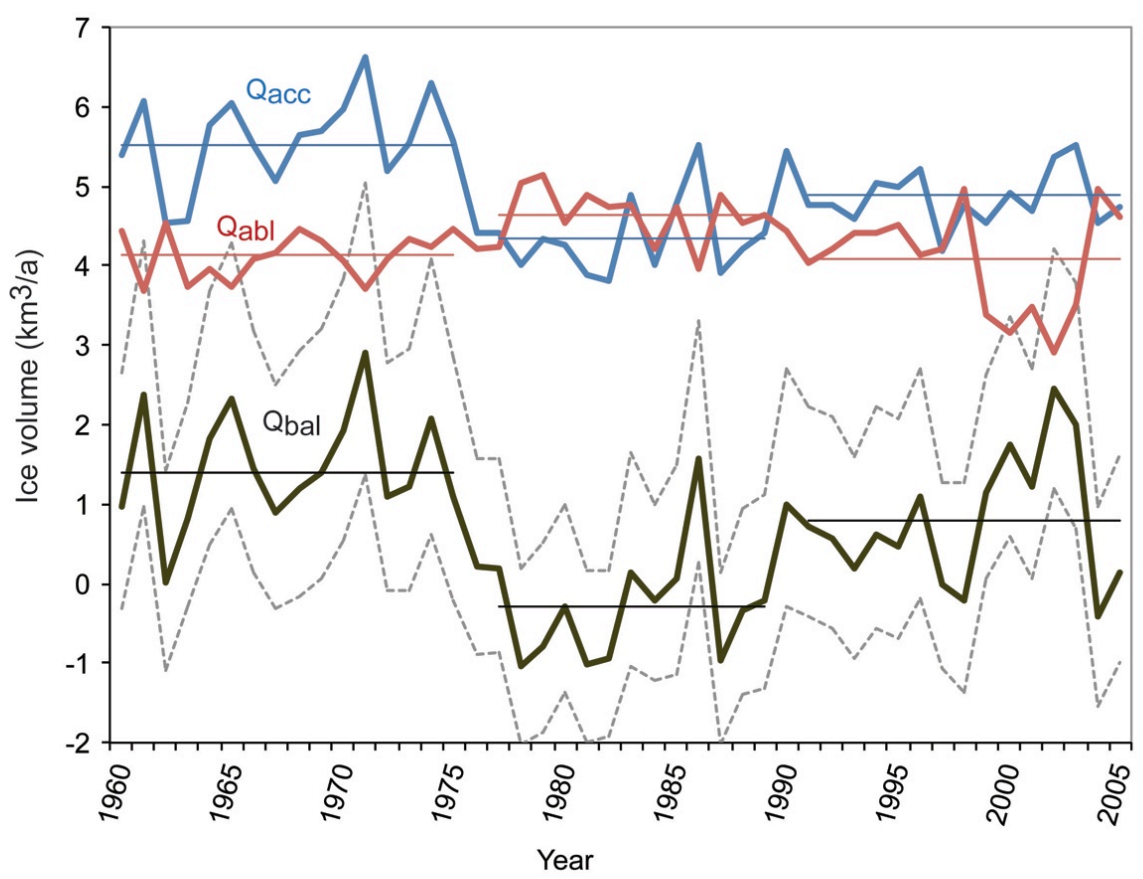

Fig. 11. Histories of annual accumulation (blue line), ablation (red line) and surface mass balance $Q_{\text {bal }}$ (black line) from 1960-2005. The three fluxes are derived from input scenario \#4 (Table 2). The upper and lower ranges of surface mass balance fluxes $Q_{\text {bal }}$, derived from the various inputs cases for accumulation fluxes $Q_{\mathrm{acc}}$ and ablation fluxes $Q_{\mathrm{abl}}$ listed in Table 2, are represented by dashed grey lines. A piecewise linear fit was chosen to indicate averages during the periods 1960-1975, 1976-1990 and 1991-2005.

basal drag across the bed, allowing us to assume $U_{\mathrm{B}}$ equals the surface velocity $U_{\mathrm{T}}$ (Howat et al., 2005); although we note that this approach will tend to overestimate the downslope ice fluxes.

\section{Results}

\subsection{Surface mass balance}

The degree-day ablation model (Eq. 1a and 1b) and precipitation model (Eq. 4) were run to calculate annual ablation $Q_{\mathrm{abl}}$, accumulation $Q_{\mathrm{acc}}$ and surface mass balance
$Q_{\mathrm{bal}}=Q_{\mathrm{acc}}-Q_{\mathrm{abl}}$ in w. eq. over the glacier for the period 1960 to 2005, summarized in Table 2 (Fig. 11). On the assumption that the uncertainties for each of the model variables in Eq. (1)-(5) (i.e., ablation co-efficients, $k(z), a(z)$, $P, T)$ are all uncorrelated, the uncertainties for each variable were propagated as the mean square error of each linear best fit correlation, and summed to produce the total error. The results of the various model runs, and the corresponding uncertainties in the range of inputs, are also summarized in Table 2 . 
Figure 11 shows annual accumulation $Q_{\text {acc }}$, ablation $Q_{\text {abl }}$ and resulting $Q_{\text {bal }}$ calculated over the glacier surface, and linear best fits for the periods 1960-1975, 1976-1990 and 1991-2005. Average ablation over the period 1960 to 2005 is $4.6 \mathrm{~km}^{3} \mathrm{a}^{-1}$. Anomalously low ablation from 1999 to 2003 was a result of anomalously low annual temperatures (see Fig. 6a). Although accumulation (snowfall) depends on the joint distribution of precipitation and temperature, the pattern of accumulation varies most closely with that of precipitation (see Fig. 6b); accumulation was relatively high during 19601975 and decreased by more than $14 \%$ during 1976-2005.

Scaling the precipitation at Laguna San Rafael as given in Eq. (4) by a constant $k=3$ over the area of the glacier (Table 1 , case 1,2 ), implies the average $Q_{\text {acc }}$ today is $\sim 4.0 \mathrm{~km}^{3} \mathrm{a}^{-1}$; using constant $k=5$ (Table 1, case 3) implies $Q_{\text {acc }}$ is $\sim 6.7 \mathrm{~km}^{3} \mathrm{a}^{-1}$; using $k(z)$ (Table 1 , case 4 ) implies $Q_{\text {acc }}$ is $\sim 5.1 \mathrm{~km}^{3} \mathrm{a}^{-1}$ (Fig. 11). The range of accumulation values from the various model runs (i.e., $k=3,5, k(z)$ ) and the range of ablation values are used to generate the full range of possible annual balance fluxes, indicated by the grey shading; the annual surface mass balance $Q_{\text {bal }}$ over the period 1960 to 2005 from case 4 (see Table 2) is indicated by the black line. The best fit $(r=0.76)$ between observations and modeled surface mass balance and annual ELA occurs when using $k(z)$ and both snow and ice degree-day coefficients in the ablation model (case 4) (see Figs. 8 and 9); we henceforth used the results of that model run to compare $Q_{\text {bal }}$ to the other fluxes in the terminus mass budget (see Fig. 11).

Surface mass balance was positive in the 1960s, negative in the late 1970s-early 1980s and again in the late 1980s, and was relatively positive from 1999 to 2003 , mainly due to reduced ablation during the latter period (Fig. 11). Average annual surface mass balance over the period 1960 to 2005, using $k(z)$ in case 4 , was $+0.71 \mathrm{~km}^{3} \mathrm{a}^{-1}$ w. eq. In other words, if the glacier had terminated on land and did not calve, other things being equal we would expect it would still be expanding to capture more surface ablation area in order to reach equilibrium with the present-day climate.

\subsection{Length changes}

An important non-climatic control on any length changes of a calving glacier is the area of the ice front in contact with fjord water and subject to submarine melt, as documented at Le Conte Glacier (Motyka et al., 2003) and more recently in west Greenland (Rignot et al., 2010). Any decrease in the cross-sectional area of the submarine ice front should diminish the volume of ice subject to melting and calving and hence decrease terminus retreat, assuming the flux of ice to the terminus does not vary significantly. Figure 4 shows that the rate of retreat of the terminus of San Rafael Glacier decreased as the cross-sectional area $\left(A_{\text {term }}\right)$ in contact with the warm brackish waters of the lagoon diminished in the early 1980s and again in the early 1990s, once the ice front retreated into the steadily narrowing but deepening outlet across the Andean range front.

The volume of ice lost from the glacier snout due to retreat during this period $\left(Q_{\text {term }}\right)$ and its variability over time can be calculated from the subsurface fjord bathymetry (Fig. 3), the height of the above board glacier surface, and the retreat rate (Fig. 4). The terminus has retreated $4 \mathrm{~km}$ during the period 1959-2005, with no documented re-advances over this time. If we assume an average ice cliff height of $40 \mathrm{~m}$ above a constant water level has persisted since 1959, the volume of ice lost from the terminus during retreat averaged $0.06 \mathrm{~km}^{3} \mathrm{a}^{-1}$ over 1959-2005, with a maximum loss of up to $0.17 \mathrm{~km}^{3} \mathrm{a}^{-1}$ during a phase of rapid retreat in the early 1980s. A second phase of rapid retreat occurred around 1990, with losses of up to $0.12 \mathrm{~km}^{3} \mathrm{a}^{-1}$. These two periods of rapid retreat followed years when the balance flux $\left(Q_{\mathrm{bal}}\right)$ was most negative, and hence less ice was arriving at the terminus. Both periods of rapid retreat ended when the terminus retreated into the narrowing outlet valley. Most notably, the mass loss from the terminus during any year of rapid retreat is only between $4 \%$ and $32 \%$ of the mass deficit from the surface balance; in other words, at least $2 / 3$ of the mass deficit during these years must be lost to thinning of the glacier itself.

\subsection{Thinning flux}

If we assume thinning rates estimated from satellite images and photos (Aniya, 1999; Rivera et al., 2007; Willis et al., 2010) and from the trimlines near the terminus averaged 2-2.3 $\mathrm{m} \mathrm{a}^{-1}$ near the current terminus, and approached 1$2 \mathrm{~m} \mathrm{a}^{-1}$ across the lower reaches of the icefield plateau, the total volume of ice lost via thinning at the glacier surface $Q_{\text {thin }}$ during 1950-2005 approaches $19 \mathrm{~km}^{3}$, with an average annual volume loss of $0.35 \mathrm{~km}^{3} \mathrm{a}^{-1}$. San Rafael glacier hence appears to have lost mass through surface lowering $\sim 6$ times, on average, the rate it lost mass through retreat of the calving front. In other words, and similar to observations from neighboring glaciers of the North Patagonian Icefield (Rivera et al., 2007), Glaciar San Rafael appears to be responding to the warmer and drier climate of the past $50 \mathrm{yr}$ by thinning much more strongly than by accelerated calving and frontal retreat.

Much of this thinning is most likely due to ice motion in the ablation zone drawing down the glacier surface. Thinning can also result from accelerated surface mass loss due to ablation rates exceeding accumulation. Most likely, thinning rates have varied significantly over the past $50 \mathrm{yr}$, and may have been particularly high during the last two decades of the 20th century (when they were last measured in detail), particularly in the period 1976-1990 when ablation fluxes exceeded accumulation fluxes by on average $0.55 \mathrm{~km}^{3} \mathrm{a}^{-1}$ and by up to $1.2 \mathrm{~km}^{3} \mathrm{a}^{-1}$ w. eq. in the ablation zone. If we assume that the calving flux must always be positive (i.e., $Q_{\text {calv }}>0$ in Eq. (7), no ice accretion at the terminus), $Q_{\text {thin }}$ must have been enhanced by excess surface melt of up to $0.9 \mathrm{~km}^{3} \mathrm{a}^{-1}$ 


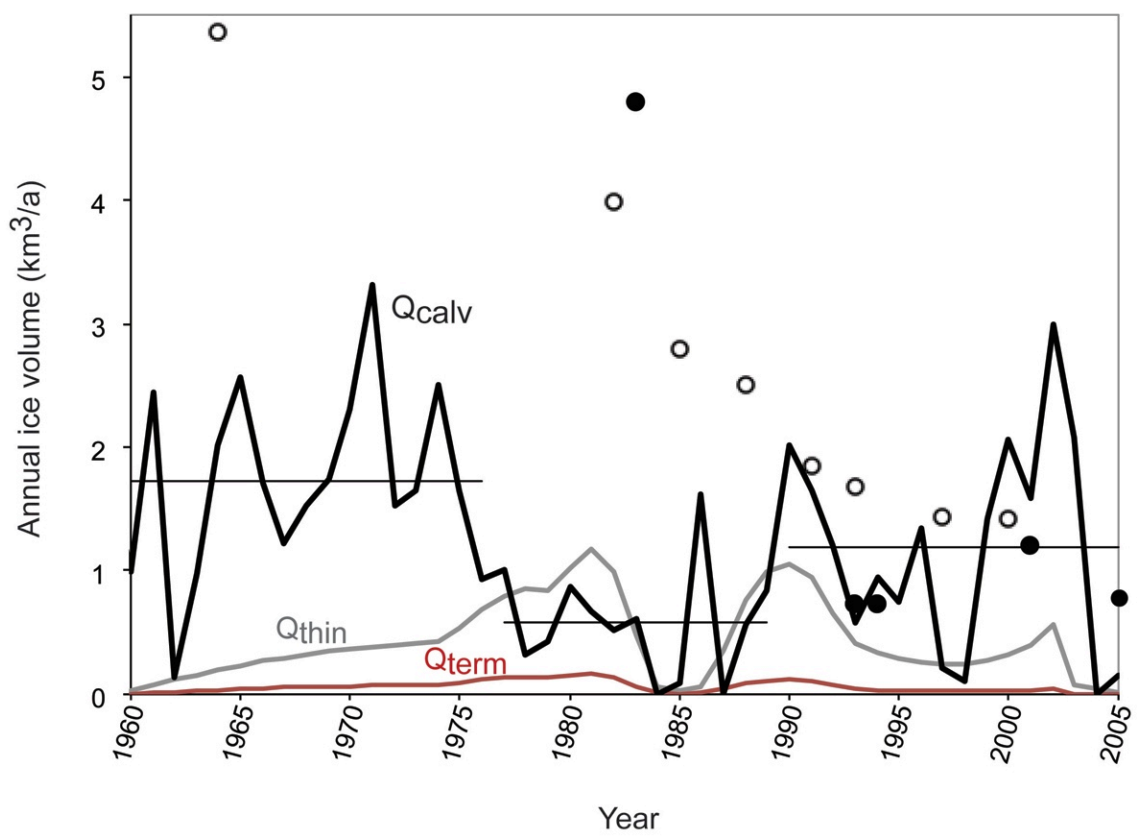

Fig. 12. Histories of surface thinning $Q_{\text {thin }}$ (grey line) ice loss from the terminus $Q_{\text {term }}$ (dark red line), and calving flux $Q_{\text {calv }}$ (black line) from 1960-2005. The calving flux $Q_{\text {calv }}$ was derived using the surface mass balance in input scenario \#4 (Fig. 11). A piecewise linear fit was chosen to indicate averages during the periods 1960-1975, 1976-1990 and 1991-2005, as in Table 2 (thin black lines). The filled dots represent observed calving fluxes used to tune the models (listed in Table 1); the open dots represent calving fluxes modeled using a "sliding law", listed in Table 3.

during 1976-1990, when $Q_{\text {bal }}$ was negative. There is certainly the possibility that there have been years in which $Q_{\text {thin }}<0$ when the climate was cooler and wetter, particularly during the period 1950-1970 and again around 19982003, although there is no observational evidence to indicate thickening of the glacier during these periods.

Given the potential influence of calving speeds and retreat of the terminus on longitudinal extension in the terminal zone (e.g., Venteris et al., 1997), the rate of dynamic surface lowering in the terminal zone must also have varied significantly during this period, but by how much is unknown, for only two direct measurements of the surface elevation of the lower reaches of the glacier exist, taken in 1975 and 2001 (Rivera et al., 2007). To first order, the rate of dynamic surface lowering at any point on the glacier is a function of the change in glacier length and the local surface slope, i.e., longitudinal profile of the glacier surface; following this logic, thinning rates decrease upglacier from the terminus. Most glaciers with large volume losses exhibit a thinning pattern that increases with altitude (Schwitter and Raymond, 1993). Since we have little data to constrain the variability in dynamic thinning rates over this period, and noting that the parabolic longitudinal glacier surface profile is roughly maintained but shifts upvalley during retreat, we can calculate the rate of ice volume decrease represented by surface lowering and infer the temporal variability in the rate of thinning by combining the retreat history and trimlines on the valley walls and either
(1) assume that an average thinning rate of $2 \mathrm{~m} \mathrm{a}^{-1}$ was maintained across the glacier surface throughout the period 19502005 (to arrive at the average thinning rate of $0.35 \mathrm{~km}^{3} \mathrm{a}^{-1}$ stated above), or (2) assume that the dynamic thinning rate equals the product of the retreat rate and surface slope of the glacier in the lower reaches of the glacier, and then decreases upglacier to vanishing values at the glacier headwall. Calculated in this latter way, and plotted in Fig. 12, the rate of ice volume lost to dynamic thinning increased to over $1 \mathrm{~km}^{3} \mathrm{a}^{-1}$ in the early 1980s and again in the late 1980s, when retreat accelerated markedly and calving rates increased. The combined thinning rate from dynamic surface lowering coupled with excess melt in the ablation zone most likely increased to almost $4 \mathrm{~m} \mathrm{a}^{-1}$ in the lower reaches of the glacier during this period.

\subsection{Budgeting the calving flux}

We modeled the calving flux in one of two ways. In our first scenario, we used the mass budget model to estimate the flux of ice delivered to and calved from the terminus over time $Q_{\text {calv }}$ using Eq. (7) and compared this flux with the annual rate of retreat. For a calving glacier in steady-state, where $Q_{\text {thin }}=0$ and $Q_{\text {term }}=0$, any $Q_{\text {bal }}>0$ must be lost through the glacier snout via calving $\left(Q_{\text {calv }}\right)$. Since the volume of San Rafael glacier has decreased through both shortening (retreat, $Q_{\text {term }}$ ) and surface lowering (thinning, $Q_{\text {thin }}$ ) 
Table 3. Modeled velocities at the terminus using sliding, lateral drag and bathymetry developed in Benn et al. (2007) and Eqs. (8-12), for years with known terminus positions and bathymetric data, and observed terminus velocities for years with available data (Kondo and Yamada, 1988; Warren et al., 1995; Rignot et al., 1996; E. Rignot, personal communication, 2003). Calving speeds calculated according to definition in Eq. (8). Calving fluxes $Q_{\text {calv }}$ calculated as product of calving speed and ice front area $A_{\text {term. }}$.

\begin{tabular}{lcccrcrrl}
\hline Year & $\begin{array}{c}\text { Modeled } \\
\text { terminus } \\
\text { velocity } \\
\left(\mathrm{km} \mathrm{a}^{-1}\right)\end{array}$ & $\begin{array}{c}\text { Observed } \\
\text { terminus } \\
\text { velocity } \\
\left(\mathrm{km} \mathrm{a}^{-1}\right)\end{array}$ & $\begin{array}{c}\text { Fjord } \\
\text { halfwidth } \\
(\mathrm{m})\end{array}$ & $\begin{array}{r}\text { Max } \\
\text { water } \\
\text { depth } \\
(\mathrm{m})\end{array}$ & $\begin{array}{r}\text { Mean } \\
\text { water } \\
\text { depth } \\
(\mathrm{m})\end{array}$ & $\begin{array}{r}\text { Retreat } \\
\text { rate }\end{array}$ & $\begin{array}{c}\text { Calving } \\
\text { speed } \\
\left(\mathrm{m} \mathrm{a}^{-1}\right)\end{array}$ & $\begin{array}{l}\text { Calving } \\
\text { flux }\end{array}$ \\
$\left(\mathrm{km} \mathrm{a}^{-1}\right)$ & $\left(\mathrm{km}^{3} \mathrm{a}^{-1}\right)$ \\
\hline 2001 & 3.40 & 3.08 & 1053 & 254 & 164 & 80 & 3.33 & 1.49 \\
1998 & 3.25 & & 1117 & 267 & 152 & 50 & 3.20 & 1.5 \\
1994 & 3.32 & $4-6$ & 1117 & 249 & 141 & 69 & 3.25 & 1.79 \\
1992 & 3.51 & & 1117 & 27 & 166 & 133 & 3.37 & 1.75 \\
1989 & 4.72 & & 1170 & 281 & 177 & 201 & 4.52 & 2.49 \\
1986 & 5.01 & & 1383 & 265 & 177 & 12 & 5.00 & 2.75 \\
1983 & 6.17 & $5-8$ & 1319 & 217 & 139 & 96 & 6.07 & 3.34 \\
1976 & 7.91 & & 1362 & 237 & 157 & 139 & 7.77 & 6.68 \\
1965 & 6.01 & & 1362 & 205 & 129 & 47 & 5.97 & 5.37 \\
1959 & 8.95 & & 1489 & 259 & 131 & 5 & 8.94 & 8.05 \\
\hline
\end{tabular}

over the past $50 \mathrm{yr}$, the calving flux $Q_{\text {calv }}$ also takes into account these ice mass losses $\left(Q_{\text {bal }}+Q_{\text {thin }}+Q_{\text {term }}\right)$, as given in Eq. (7). Using this approach and our mass budget model with best fit scenario (case 4, where precipitation scales with $k(z)$ and using the ablation co-efficients prescribed in Eq. 1a and $1 \mathrm{~b}$ ), the calving flux during the period 1960 to 2005 averaged $1.01 \mathrm{~km}^{3} \mathrm{a}^{-1}$ (black line in Fig. 12), similar to fluxes calculated using InSAR in 2001.

As seen in Fig. 12 and Table 2, $Q_{\text {calv }}$ as modeled using the mass budget has also varied significantly during the past half century. For example, $Q_{\text {calv }}$ averaged $1.8 \mathrm{~km}^{3} \mathrm{a}^{-1}$ during the period 1960-1975, and decreased to less than $0.7 \mathrm{~km}^{3} \mathrm{a}^{-1}$ in the 1980s, a decade when surface melt rates increased and snow accumulation decreased so that all new accumulation was lost through ablation and all calving resulted in net volume loss from the glacier. $Q_{\text {calv }}$ slowly increased in the late 1990 s to over $3 \mathrm{~km}^{3} \mathrm{a}^{-1}$, and decreased again in the first years of the 21 st century. The corresponding calving velocities range from $<1 \mathrm{~km} \mathrm{a}^{-1}$ to $>7 \mathrm{~km} \mathrm{a}^{-1}$ over the 1960 2005 period, in agreement with observations (Naruse, 1985; Kondo and Yamada, 1988; Rignot et al., 1996; Willis et al., 2010), and averaged $1.86 \mathrm{~km} \mathrm{a}^{-1}$.

\subsection{Calving fluxes modeled using the sliding law}

The modeled annual velocities at the terminus using the second calving model, where the calving flux is driven by sliding at the terminus, with $C=0.6$ and constrained by the known terminus positions and water depths from Figs. 3 and 4, are listed in Table 3. The modeled velocities agree well with the observed surface velocities at the terminus from 1983, 1994, and 2001. Terminus velocities were very large between 1959-1979 (6-9 $\left.\mathrm{km} \mathrm{a}^{-1}\right)$ when the glacier extended a con- siderable distance into Laguna San Rafael and had substantially lower values of lateral drag. As the glacier receded to its present day position in the narrowing fjord, velocities decreased to $\sim 3.3 \mathrm{~km} \mathrm{a}^{-1}$. Retreat rates are relatively insignificant $\left(<200 \mathrm{~m} \mathrm{a}^{-1}\right)$ compared with the large velocities modeled at the terminus of the glacier, thus calving speeds were almost equal to down-glacier velocity (see Eq. 8). The resulting calving fluxes (the product of the calving velocity $U_{\mathrm{D}}$ multiplied by the terminus cross-sectional area $A_{\text {term }}$ ) follow a similar trend to the results from the mass budget model in Sect. 5.4, however, the magnitude of the calving fluxes range from $\sim 6 \mathrm{~km}^{3} \mathrm{a}^{-1}$ during $1960-1975$, to $2.85 \mathrm{~km}^{3} \mathrm{a}^{-1}$ during 1976-1990, to $1.63 \mathrm{~km}^{3} \mathrm{a}^{-1}$ as of 1990 (open dots in Fig. 12), exceeding those of the mass budget model (black line in Fig. 12) by between $40 \%$ and $300 \%$.

The widely divergent results between the mass budget model and the sliding law model is an intriguing result of the study. It should be noted that calving laws are notoriously inexact, and have often been tuned to a single glacier system, where causal relationships may not translate to other systems. One possible reason for this is that stretching rates and crevasse formation are not taken into account in either the calving laws or observed calving rates based on surface feature tracking to derive downslope ice speeds (but should not effect calving fluxes measured based on iceberg volume, as calculated by Warren et al., 1995 in 1993), and hence both approaches may grossly overestimate the actual flux of ice (see Venteris, 1999). This would result in the mass budget model (which is tuned to the sparse observations of ELA, accumulation and ablation, but not calving) producing calving fluxes that are less than (1) the observed rates of calving and (2) the modeled calving rates based on the sliding law, as we see and have show in Fig. 12. 
The results from the "sliding law" model in Table 3 indicates a relatively robust correlation $\left(r^{2}=0.76\right)$ between the half width of the fjord channel and the modeled glacier velocity, suggesting that modeled ice velocities are driven primarily by changes in the channel width, where wide channels allow for substantially lower values of lateral drag. In assuming plug flow in Eq. (12), it follows that the sliding velocity is most sensitive to changes in both ice thickness $H_{\mathrm{T}}$ relative to water depth and the glacier channel half-width $W$. By comparison, the sliding model also indicates a negligible dependence on water depths: modeled calving velocities did not correlate with either mean water depth $\left(r^{2}=0.0008\right)$ or maximum water depth $\left(r^{2}=0.014\right)$.

Sensitivity analyses, carried out using the 2001 modeled calving velocity for its relatively good fit with observations (E. Rignot, personal communication, 2003; Willis et al., 2010), suggest that the calving velocity is particularly susceptible to changes in tuning parameter $C$, in Eq. (11). Peak calving velocities occur when $C>3$, where terminus velocities approach $16 \mathrm{~km} \mathrm{a}^{-1}$ and any further increases in $C$ have very little consequence. Similarly, when $C$ approaches 0 , the calving velocity also decreases rapidly, until it approaches zero. Raising the height above waterline $\left(H_{0}\right)$, adding to the vertical ice face at the terminus, also decreases ice velocity. Although an increase in ice thickness should enhance the driving stress, it increases basal drag more substantially. While the driving stress is tempered by a low slope angle $\theta$, the loading of ice onto the terminus will increase the downward pressure, increasing basal shear and lowering flow rates. Increasing the surface slope of the glacier, assuming there are no other changes to the system, results in a power law increase in terminus velocity and hence calving rate. Small increases in slope of the glacier would result in significant increases in the terminus velocity, allowing for rapid surges and appreciable increases in calving. This, however, assumes that the same thickness of ice, and therefore the same downward acting forces will drive glacier flow. In reality, we would expect to see significant thinning associated with any increase in glacier slope, which has the potential to further enhance calving velocities.

The modeled calving fluxes using Benn et al.'s "sliding laws", although greater than both observed and modeled mass balance fluxes, indicate a high degree of correlation between channel width, flow speed and calving rate. This behavior is key to understanding why most stable tidewater glaciers have termini located at topographic narrows, and why calving fluxes at Glaciar San Rafael decreased 2-5 fold, regardless of model scenario used, when the terminus retreated into the narrowing outlet east of the Andean range front. However, the difference in the magnitude of the calving fluxes $Q_{\text {calv }}$ between the sliding law model and mass balance model also suggests that calving dynamics may be more variable than our simple approximation of plug flow and lateral drag, as used in Eqs. (10)-(12), would reflect.

\subsection{Calving vs. retreat rates}

Several studies have suggested that pronounced longitudinal stretching of glacier ice in the terminal zone may be a fundamental feature of rapidly calving tidewater glaciers, promoting calving rates in excess of the balance flux of the glacier and resulting in retreat (e.g., Meier and Post, 1987; Venteris et al., 1997; Benn et al., 2007). If terminus retreat varies with increases in ice delivery to the terminus, as has been observed at other calving glaciers in the past decade (e.g., Howat et al., 2005; Luckman et al., 2006), retreat rates should increase in concert with increases in this calving flux. Our mass budget model results suggest the contrary, however; retreat rates appear to have increased during periods when the calving flux decreased in the early 1980s and 1990s, while a short period of rapid retreat in the first few years of the 21 st century appears to coincide with an increase in the calving flux. This relationship holds whether the calving flux is modeled using an ice mass budget (Sect. 5.4) or using terminus velocities and ice front bathymetry (Sect. 5.5).

While we expect calving and terminus retreat to vary widely from glacier to glacier as each are dependent upon other factors, including the balance flux to the terminus and the rate of thinning (see Eq. 6), that the rate of retreat for San Rafael does not appear to co-vary with the calving flux in our models, and in fact, contrary to expectations appears predominantly out of phase with $Q_{\text {calv }}$. These results appear robust, but do suggest that several of our inputs, assumptions and sensitivities need revisiting. In particular, caution is needed with regard to (a) assuming that surface lowering occurs exclusively due to dynamic thinning, (b) focusing the concentration of orographic precipitation around the ELA zone when using the surface mass balance to drive the model of ice fluxes, and (c) deriving basal sliding velocities and terminal ice fluxes from remotely sensed surface velocities, which do not take into account longitudinal stretching and crevasse opening.

\section{Implications for future behaviour}

The geometry of Glaciar San Rafael, with a broad, relatively flat accumulation area and ELA zone funneled into a narrow constriction across the hanging wall of the Liquine-Õfqui fault and into Laguna San Rafael, renders the glacier capable of withstanding a substantially warmer and drier climate without necessarily resulting in retreat of the glacier snout. The rate of retreat is a function of competing influences between both climate and terminus geometry. For example, in 1986, when the terminus retreated across the rangefront and into the narrow valley constriction, retreat temporarily slowed, although calving speeds most probably did not. Moreover, although the terminus has not retreated substantially during the past few decades, the entire glacier has thinned significantly (Rivera et al., 2007) due to warming 
since the early 1980s. While a negative balance flux will contribute to increasing the retreat rate, accelerated thinning will retard it, so the two climatic drivers may be offsetting each other at San Rafael Glacier.

Contrary to what has been observed at other tidewater glaciers, such as the outlet glaciers of Greenland (Thomas et al., 2003; Howat et al., 2005; Stearns and Hamilton, 2007) or Marinelli Glacier in Tierra del Fuego (Koppes et al., 2009), negative balance flux and accelerated surface thinning at Glaciar San Rafael over the past few decades have not (as of yet) resulted in a substantial increase in the rate of terminus retreat. However, considering the ice thickness at the ELA is estimated to be only $\sim 400 \mathrm{~m}$ (Rignot et al., 2003), continuous thinning rates of $1-2 \mathrm{~m} \mathrm{a}^{-1}$ over the broad plateau of the icefield, where the ELA is located, would remove most of the glacier (and potentially most of the North Patagonian Icefield) within a few hundred years. Such substantial changes in the balance flux and the ice thickness would also affect buoyancy at the glacier terminus. Furthermore, continuous rapid calving rates into water depths of $\sim 210 \mathrm{~m}$ will likely destabilize the terminus and result in drastic retreat in the coming decades.

\section{Conclusions}

The annual budget of ice into and out of Glacier San Rafael over 1950-2005 was reconstructed using daily values of key climate variables from the NCEP-NCAR global reanalysis climate dataset and a compendium of historical observations. Using a DEM of the glacier surface and this reanalysis dataset, constrained by a sparse collection of direct measurements of local temperature, precipitation, ablation and thinning collected over the past few decades and a documented retreat of the terminus over the past $\sim 50 \mathrm{yr}$, we are able to estimate the annual accumulation, ablation and thinning fluxes over the glacier and the corresponding calving flux from the terminus during this time.

San Rafael glacier experienced a period of accelerated retreat starting around 1975 through the early 1990s, a period when accumulation decreased and ablation increased. Terminus retreat rates have been relatively low over the most recent decade, in part because the glacier is still experiencing rapid ice flow to the terminus and because it has retreated into a narrow outlet, limiting the contribution of ice-front melt to the overall mass loss. If our flux analysis is valid, the decrease in net accumulation and increase in ablation over the last few decades, as the climate has become warmer and drier, has primarily resulted in pervasive thinning through both surface mass loss and accelerated flow to the terminus, which has retarded terminus retreat. For Glaciar San Rafael, and possibly all glaciers of similar geometry with a broad plateau at the ELA and a narrow outlet, response to climate changes are reflected primarily in changes in the rate of surface thinning and the calving speed, and only secondarily in changes in terminus position, emphasizing the complex dynamics between climate inputs and glacier response.

Constrained by a few direct observations of Glaciar San Rafael's dynamics over the past few decades, we have calculated accumulation and ablation rates as a function of surface elevation to reconstruct the changing flux of ice to the terminus over the past $\sim 50 \mathrm{yr}$. Our mass budget approach is compared to a reconstructed calving flux using theoretical calving and sliding laws, and suggest that the trends in calving fluxes are robust, with calving rates decreasing during periods of rapid retreat in the late 1970s and 1980s; however, applying a "calving law" approach increases modeled calving rates by $40-300 \%$. Our approach provides a simple reconstruction of the time-varying budget of ice through San Rafael glacier using sparse empirical data which, when compared with the history of the terminus retreat gleaned from maps, aerial photos and satellite images, as well as with topographic and bathymetric constraints of the lagoon into which it calves, illuminates the relative importance of climatic and non-climatic controls on glacier retreat on annual to decadal time scales.

Acknowledgements. This work was supported by US NSF grant OPP-0338371 (Koppes), and NASA subcontract \#1267029 through Eric Rignot at JPL (Conway and Rasmussen). We thank Bernard Hallet for stimulating discussions and support of this work. We are most grateful to Gerard Roe for assistance with the orographic model, Andres Rivera for providing the Landsat imagery used in Fig. 1, Harvey Greenberg for assistance with the DEM construction, and Drew Stolar for assistance with GIS and MATLAB processing of the datasets.

Edited by: G. H. Gudmundsson

\section{References}

Aniya, M.: Glacier inventory for the Northern Patagonia Icefield, Chile, and variations $1944 / 45$ to $1985 / 86$, Arctic Alpine Res., 20, 179-187, 1988.

Aniya, M.: Recent glacier variations of the Hielos Patagonicos, South America, and their contribution to sea-level change, Arct. Antarct. Alp. Res., 31, 144-152, 1999.

Araneda, A., Torrejón, F., Aguayo, M., Torres, L., Cruces, F., Cisternas, M., and Urrutia, R.: Historical records of San Rafael Glacier advances (North Patagonian Icefield): another clue to "Little Ice Age" timing in southern Chile?, Holocene, 17, 987998, 2007.

Benn, D. I., Hulton, N. R. J., and Mottram, R. H.: Calving laws, "sliding laws" and the stability of tidewater glaciers, Ann. Glaciol., 46, 123-130, 2007.

Carrasco, J., Casassa, G., and Rivera, A.: Meteorological and climatological aspects of the Southern Patagonia Icefield, in: The Patagonian ice fields: a unique natural laboratory for environmental and climate change studies, edited by: Casassa, G., Sepulveda, F. V., and Sinclair, R., New York, Kluwer Academic/Plenum Publishers, 29-41, 2002. 
Cook, K. H., Yang, X., Carter, C. M., and Belcher, B. N.: A modeling system for studying climate controls on mountain glaciers with application to the Patagonian Icefields, Climate Change, 56, 339-367, 2003.

Dyurgerov, M. B. and Meier, M. F.: Mass balance of mountain and subpolar glaciers: a new global assessment for 1961-1990, Arctic Alpine Res., 29, 379-391, 1997.

Enomoto, H. and Nakajima, C.: Recent climate-fluctuations in Patagonia, in: Glaciological Studies in Patagonia Northern Icefield 1983-1984, edited by: Nakajima, C., Nagoya (Japan), 7-14, 1985.

Escobar, F., Vidal, F., Garin, R., and Naruse, R.: Water balance in the Patagonain Icefield, in: Glaciological Researches in Patagonia, 1990, edited by: Naruse, R. and Aniya, M., Nagoya (Japan), 109-119, 1992.

Fujiyoshi, Y., Kondo, H., Inoue, J., and Yamada, T.: Characteristics of precipitation and vertical structure of air temperature in northern Patagonia, Bull. Glacier Res., 4, 15-24, 1987.

Hock, R.: Temperature index melt modeling in mountain areas, J. Hydrol., 282, 104-115, 2003.

Hofer, M., Mölg, T., Marzeion, B., and Kaser, G.: Empiricalstatistical downscaling of reanalysis data to high-resolution air temperature and specific humidity above a glacier surface (Cordillera Blanca, Peru), J. Geophys. Res., 115, D12120, doi:10.1029/2009JD012556, 2010.

Howat, I. M., Joughin, I., Tulaczyk, S., and Gogineni, S.: Rapid retreat and acceleration of Helhiem Glacier, east Greenland, Geophy. Res. Lett., 32, L22502, doi:10.1029/2005GL024737, 2005.

Hubbard, A. L.: Modelling climate, topography and paleoglacier fluctuations in the Chilean Andes, Earth Surf. Proc. Land., 22, 79-92, 1997.

Hulton, N., Sugden, D., Payne, A., and Clapperton, C.: Glacier modeling and the climate of Patagonia during the Last Glacial Maximum, Quaternary Res., 42, 1-19, 1994.

Kalnay, E., Kanamitsu, M., Kistler, R., Collins, W., Deaven, D., Gandin, L., Iredell, M., Saha, S., White, G., Woollen, J, Zhu, Y., Chelliah, M., Ebisuzaki, W., Higgins, W., Janowiak, J., Mo, K. C., Ropelewski, C., Wang, J., Leetmaa, A., Reynolds, R., Jenne, R., and Joseph, D.: The NCEP/NCAR 40-year reanalysis project, B. Am. Meteorol. Soc., 77, 437-471, 1996.

Kerr, A. and Sugden, D.: The sensitivity of the South Chilean snowline to climatic change, Climatic Change, 28, 255-272, 1994.

Kistler, R., Kalnay, E., Collins, W., Saha, S., White, G., Woollen, J., Chelliah, M., Ebisuzaki, W., Kanamitsu, M., Kousky, V., van de Dool, H., Jenne, R., and Fiorino, M.: The NCEP-NCAR 40year reanalysis: monthly means CD-ROM and documentation, B. Am. Meteorol. Soc., 82, 247-267, 2001.

Kobayashi, S. and Saito, T.: Meteorological observations on Soler Glacier, in: Glaciological Studies in Patagonia Northern Icefield 1983-1984, edited by: Nakajima, C., Nagoya (Japan), 32-36, 1985.

Kondo, H. and Yamada, T.: Some remarks on the mass balance of the terminal-lateral fluctuations of San Rafael Glacier, the Northern Patagonia Icefield, Bull. Glacier Res., 6, 55-63, 1988.

Koppes, M., Hallet, B., and Anderson, J.: Synchronous acceleration of ice loss and glacier erosion, Marinelli Glacier, Tierra del Fuego, J. Glaciol., 55, 207-220, 2009.

Koppes, M., Sylwester, R., Rivera, A., and Hallet, B.: Sediment yields over an advance-retreat cycle of a calving glacier, Laguna
San Rafael, North Patagonian Icefield, Quaternary Res., 73, 8495, 2010.

Koppes, M. N.: Glacier erosion and response to climate, from Alaska to Patagonia, University of Washington, Ph.D. thesis, 228 pp., 2007.

Lamy, F. J., Kaiser, J., Ninnemann, U., Hebbeln, D., Arz, H. W., and Stoner, J.: Antarctic timing of surface water changes off Chile and Patagonian ice sheet response, Science, 304, 9591962, 2004.

Luckman, A., Murray, T., de Lange, R., and Hanna, E.: Rapid and synchronous ice-dynamic changes in East Greenland, Geophys. Res. Lett., 33, L03503, doi:10.1029/2005GL025428, 2006.

Matsuoka, K. and Naruse, R.: Mass balance features derived from a firn core at Hielo Patagonico Norte, South America, Arct. Antarct. Alp. Res., 31, 333-340, 1999.

Mayr, C., Wille, M., Haberzetti, T., Fey, M., Janssen, S., Lucke, H., Ohlendorf, C., Oliva, G., Schabitz, F., Schleser, G. H., and Zolitschka, B.: Holocene variability of the Southern Hemisphere westerlies in Argentinean Patagonia ( $\left.52^{\circ} \mathrm{S}\right)$, Quaternary Sci. Rev., 26, 579-584, 2007.

Meier, M. F. and Post, A.: Fast tidewater glaciers, J. Geophys. Res., 92, 9051-9058, 1987.

Motyka, R. J., Hunter, L., Echelmeyer, K. A., and Connor, C.: Submarine melting at the terminus of a temperate tidewater glacier, LeConte Glacier, Alaska, U.S.A., Ann. Glaciol., 36, 57-65, 2003.

Naruse, R.: Flow of Soler Glacier and San Rafael Glacier, in: Glaciological Studies in Patagonia Northern Icefield 1983-1984, edited by: Nakajima, C., Nagoya (Japan), 32-36, 1985.

Nye, J. F.: The flow of a glacier in a channel of rectangular elliptic and parabolic cross-section, J. Glaciol., 5, 661-690, 1965.

Ohata, T., Enomoto, H., and Kondo, H.: Characteristic of ablation at San Rafael Glacier, in: Glaciological Studies in Patagonia Northern Icefield 1983-1984, edited by: Nakajima, C., Nagoya (Japan), 37-45, 1985a.

Ohata, T., Kondo, H., and Enomoto, H.: Meteorological observations at San Rafael Glacier, in: Glaciological Studies in Patagonia Northern Icefield 1983-1984, edited by: Nakajima, C., Nagoya (Japan), 22-31, 1985b.

O’Neel, S., Pfeffer, W. T., Krimmel, R., and Meier, M.: Evolving force balance and Columbia Glacier, Alaska, during rapid retreat, J. Geophys. Res., 110, F03012, doi:10.1029/2005JF000292, 2005.

Pfeffer, W. T.: A simple mechanism for irreversible tidewater glacier retreat, J. Geophys. Res., 112, F03S25, doi:10.1029/2006JF000590, 2007.

Powell, R. D.: Grounding-line systems as second-order controls on fluctuations of tidewater termini of temperate glaciers, in: Glacial marine sedimentation; Paleoclimatic significance, Geological Society of America Special Paper 261, edited by: Anderson, J. B. and Ashley, G. M., 75-94, 1991.

Rasmussen, L. A. and Conway, H.: Estimating South Cascade Glacier (Washington, U.S.A.) mass balance from a distance radiosonde and comparison with Blue Glacier, J. Glaciol., 47, 579588, 2001.

Rasmussen, L. A., Conway, H., and Raymond, C. F.: Influence of upper-air conditions on the Patagonia icefields, Global Planet. Change, 59, 203-216, 2007.

Rignot, E., Forster, R., and Isacks, B.: Interferometric radar 
observations of Glaciar San Rafael, Chile, J. Glaciol., 42, 279291, 1996.

Rignot, E., Rivera, A., and Casassa, G.: Contribution of the Patagonia Icefields of South America to sea level rise, Science, 302, 434-437, 2003.

Rignot, E., Koppes, M., and Velicogna, I.: Rapid submarine melting of the calving faces of west Greenland glaciers, Nat. Geosci., 3, 187-191, 2010.

Rivera, A., Benham, T., Casassa, G., Bamber, J., and Dowdeswell, J.: Ice elevation and areal changes of glaciers from the North Patagonia Icefield, Chile, Global Planet. Change, 59, 126-137, doi:10.1016/j.gloplacha.2006.11.037, 2007.

Roe, G. H.: Orographic precipitation, Ann. Rev. Earth Pl. Sc., 33, 645-671, 2005.

Schwitter, M. P. and Raymond, C. F.: Changes in the longitudinal profiles of glaciers during advance and retreat, J. Glaciol., 39, 582-590, 1993.

Smith, R. B. and Barstad, I.: A linear theory of orographic precipitation, J. Atmos. Sci., 61, 1377-1391, 2004.

Stearns, L. A. and Hamilton, G. S.: Rapid volume loss from two East Greenland outlet glaciers quantified using repeat stereo satellite imagery, Geophys. Res. Lett., 34, L05503, doi:10.1029/2006GL028982, 2007.

Thomas, R. H., Abdalati, W., Frederick, E., Krabill, W. B., Manizade, S., and Steffen, K.: Investigation of surface melting and dynamic thinning on Jakobshavn Isbrae, Greenland, J. Glaciol., 49, 231-239, 2003.

Van der Veen, C.: Tidewater calving, J. Glaciol., 42, 375-385, 1996.
Venteris, E. R.: Rapid tidewater glacier retreat: a comparison between Columbia Glacier, Alaska and Patagonian calving glaciers, Global Planet. Change, 22, 131-138, 1999.

Venteris, E. R., Whillans, I. M., and Van der Veen, C. J.: Effect of extension rate on terminus positions, Columbia Glacier, Alaska, USA, Ann. Glaciol., 24, 49-53, 1997.

Warren, C. R.: Rapid recent fluctuations of the calving San Rafael Glacier, Chilean Patagonia: climatic or non-climatic?, Geogr. Ann. A, 75, 111-125, 1993.

Warren, C. R. and Aniya, M.: The calving glaciers of southern South America, Global Planet. Change, 22, 59-77, 1999.

Warren, C. R. and Sugden, D. E.: The Patagonian Icefields: a glaciological review, Arctic Alpine Res., 25, 316-331, 1993.

Warren, C. R., Glasser, N. F., Harrison, S., Winchester, V., Kerr, A., and Rivera, A.: Characteristics of tide-water calving at Glaciar San Rafael, Chile, J. Glaciol., 41, 273-289, 1995.

Willis, M. J., Melkonian, A. K., Pritchard, M. E., and Bernstein, S.: Remote sensing of velocities and elevation changes at outlet glaciers of the Northern Patagonian Icefield, Chile, International Glaciological Conference Ice and Climate Change: A View from the South. Valdavia, Chile, February 2010.

Wratt, D. S., Revell, M. J., Sinclair, M. R., Gray, W. R., Henderson, R. D., and Chater, A. M.: Relation between mass properties and mesoscale rainfall in New Zealand's Southern Alps, Atmos. Res., 52, 261-282, 2000.

Yamada, T.: Glaciological characteristics revealed by $37.6 \mathrm{~m}$ deep core drilled at the accumulation area of San Rafael Glacier, the Northern Patagonia Icefield, Bull. Glacier Res., 4, 59-67, 1987. 